AÜIFD Cilt XLIII (2002) Sayı 1 s. 231-262

\title{
XVI. Yüzyıl Bazı Osmanlı Mimarları
}

\author{
Abdulkadir DÜNDAR \\ Yrd. Doç. Dr., Ankara Üniversitesi İlâhiyat Fakültesi \\ e-mail:dundar@divinity.ankara.edu.tr
}

Some Ottoman Archtects In The Suxteenth Century. In this article I investigate the contributions of 107 relatively unknown architects to the Ontoman architecture in the sixteenth century. The study basically depends upon the research done in the Ottoman Archives and Topkapl Palace Museum Archives and it is therefore restricted to the information found in the archival documents. Even though the study briefly touches on the works of Sinan and Davud Aga, who are the most famous architects of the sixteenth century, it mainly aims to introduce the unknown architects of this century and their works.

Key words: Architect. Architecture, Monuments, Mosque, Architects of Hassa, Building, Salary (ulûfe), Citadel.

Osmanlı Arşivi ile Topkapı Sarayı Müzesi Arşivi’nde belirli zamanlarda yaptığımız çalışmaların neticesinde ortaya çıkan bu araştırmamızda, XVI. yüzyılın ilk çeyreğinden sonuna kadar geçen zaman diliminde faaliyet gösterip de incelenen arşiv belgelerinde tespit edilen ve fazla bilinmeyen yeni mimarları ortaya koymaya çalıştık. Dolayısıyla amacımız, XVI. yüzyıldaki bilinen meşhur mimarlar hakkındaki bilgileri tekrarlamak olmayıp, bugün isimlerini dahi bilmediğimiz pek çok mimarı belgelerdeki bilgilerin arasından alıp gün yüzüne çıkarmaktır. Bu nedenle Mimar Sinan ve Mimar Davud Ağa gibi dönemin hem çok önemli hem de incelenen mimarların hocaları ve yöneticileri konumundaki mimarlara ise sadece yeri geldikçe bazı atıflarda bulunduk. 
Bir dönemin sanat, mimarî anlayışının ve üslup gelişmelerinin bütün yönleriyle ortaya konulmasında, o dönemin sosyal, kültürel ve ekonomik yapısının bilinmesi kadar günümüze ulaşan veya ulaşmayan mimar̂́ yapıların inşalarında emeği geçen sanatçı ve mimarların bilinmesinin de önemli bir rolü vardır. Bu bağlamda, XVI. yüzyılda Osmanlı topraklarında çalışan mimarların bilinmesi bu yüzyılda inşa edilen yapıların daha sağlıklı değerlendirilmesine elbette katkıda bulunacaktır. Ayrıca Mimar Sinan'ın yetiştirdiği ve birlikte çalıştığı mimarların ortaya konulması, Hassa Mimarlar Ocağı'nın XVI. yüzyıldaki yapısı ve faaliyetlerine ışık tutacağı gibi, bu dönemde yapılan eserlerde Mimar Sinan'ın rolü ve katkısı konusunun daha da aydınlanmasını sağlayacaktır.

XVI. yüzyıl mimarlarından Mehmed Çavuş, Kara Mustafa, Zeynizade, Cemaleddin, Todoros, Musluhiddin, Sefer, Kalender, Yahya, Ferhad Çavuş, İbrahim Bey ve Mehmed bin Zeynelabidin adlı on iki mimarı bir başka çalışmamızda ele aldığımız için burada bunlar hakkında tekrar bilgi vermedik.' Yaptığımız tespitlere göre yukarıda belirttiğimiz zaman diliminde faaliyet gösteren mimarların sayısı 119 dır. Bu dönemde bütün Osmanlı coğrafyasında faaliyet gösteren mimar sayısının bundan ibaret olduğunu ileri sürmek elbette mümkün değildir. Çünkü, gerek Osmanlı Arşivi’nde gerekse Topkapı Sarayı Müzesi Arşivi'nde yapılacak daha kapsamlı ve uzun süreli çalışmalarda yeni mimarlar ve çalışıkları yapıları tespit etmek mümkündür. Ayrıca bu çalışmayı hazırlarken, gerek Osmanlı Arşivi'nde ve gerekse Topkapı Sarayı Müzesi Arşivi'ndeki XVI. yüzyıla ait pek çok belge ve defterleri inceleme firsat ve zamanını bulamadığımızı da belirtmek gerekir.

Çalışmamız, Osmanlı Arşivi'ndeki Kamil Kepeci Tasnifi'nde yer alan sekiz defterden alınan bilgiler başta olmak üzere Mühimme Defterleri, Maliyeden Müdevver Defterler ve Küçük Rûznâmçe Kalemi'nden bir defter ile Topkapı Sarayı Müzesi Arşivi'ndeki beş defterden tespit ettiğimiz bilgilere dayanmaktadır. Ancak, yeri geldikçe bazı tarihî kaynaklar ve diğer araştırmalardan da istifade ettik.

Osmanlı mimarlarıyla ilgili arşiv belgeleri ve kayıtlardaki bilgilerin genellikle mimarların Hassa mimarlığına atanmaları, azledilmeleri, ücretleri, bir yapının inşa veya tamirinde görevlendirilmeleri ile yaptıkları faaliyetlerde gösterdikleri başarıya göre ulûfelerine veya yevmiyelerine yapılan zamlarla alakah olduğu gözlenmektedir. Dolayısıyla mimarların inşa veya tamirinde çalıştıkları yapıların sanat ve mimarî yönleriyle ilgili görüşleri ve kendi aralarında yaptıkları tartışmalar veya mimarbaşı ile yapılar hakkındaki görüşmeleriyle ilgili olarak arşivlerde yaptığımız araştırmalarda şimdilik herhangi bir bilgi veya belgeye rastlayamadık. Bu nedenle aşağıda anlatmaya çalıştığımız mimarlar hakkındaki bilgilerin bu çerçevede olduğu göz ardı edilmemelidir. Ayrıca, genel olarak arşiv belgelerinden tespit ettiğimiz 107 mimarı, kayıtlardaki tarihlere göre bir tasnife tabi tutarak, kronolojik sırayla anlatmaya gayret ettik.

\footnotetext{
${ }^{1}$ Bkz. Abdulkadir Dündar. "XVI. Yüzyılda Suriye, Mısır vc.Suudi Arabistan'daki İmar ve Insâ Faaliyetlcrine Katkıda Bulunan Bazı Osmanlı Mimarları", Ortadoğu'da Osmanlı Dônemi Kültür Izleri Uluslararası Bilgi Söleni Bildirileri (25-27 Ekim Hatay, 28 Ekim İskenderun), Cilt: I. Atatürk Kültür Merkezi YayınIarı, Kongre ve Sempozyum Bildirileri Dizisi / 20, Ankara 200 I, s. 219-228.
} 


\section{1-MİMARBAŞI ALÂEDDIN}

Mimarbaşı Alâeddin'in ismine 932/1525-1526 tarihli bir hesap defteri ${ }^{2}$ ile Ağayân-1 Ehl-i Hiref'e dahil olan meslek başkanlarının 932-933/1526-1527 yıllarında aldıkları ücreti gösteren başka bir defterde ${ }^{3}$ rastlanılmaktadır. Hesap defterinde de Alâeddin'in ismi "Cemaat-l Ağayân-ı Ehl-i Hiref" başlığı altında "Mimarbaşı Alâeddin fi yevm kırkbeş akçe fi şehr 1327 akçe" şeklinde geçmektedir. ${ }^{4}$ Bu bilgilerden 1525-1526 yılında Alâeddin'in Mimarbaşı olduğu, günlük 45 akçeye çalıştığı ve ayda 1327 akçe aldığı anlaş̧ımaktadır. Diğer defterde Mimarbaşı Alâeddin'in günlük aldığı ücrete yer verilmezken 1526 ve 1527 yıllarında da yine 1327 akçe ulûfe aldığı belirtilmektedir. ${ }^{5}$

Rıfkı Melûl Meriç, 1509 yılı Ekim ayının başından itibaren kayıtlarda İstanbul II. Beyazid Câmii mimarı ve aynı zamanda mimarbaşılık görevini yürüten Yakubşah' $n^{6}$ isminin belirtilmemesinden onun vefat etmiş olabileceği sonucunu çıkararak, mimarbaşılık görevine Ali bin Abdullah'ın geçtiğini ileri sürmektedir?' Bazı araştırmacılar da, yukarıda belirttiğimiz Mimarbaşı Alâeddin'i Mimar Ali olarak tanıtarak, Mimar Sinan'dan önce Ser Mi'mârân-ı Hassa' lık görevinde bulunduğunu 1537-38'de ölümü üzerine bu göreve Mimar Sinan'ın atandığını belirtmektedirler. ${ }^{8}$ Ancak, Rıfkı Melûl Meriç 8 Rebiyülevvel 917/6 Haziran 1511 ve 13 Cemaziyelevvel 917/9 Ağustos 1511 tarihli kayıtlarda "cemaat-ı mi'mârân"da adı geçmeyip de o dönemin mimarlarından olduğunu belirttiği Alâeddin adlı bir mimardan daha bahsetmektedir. ${ }^{9}$ Acaba bu Mimar Alâeddin 1525-1527 yıllarına ait kayıttlarda Mimarbaşı Alâeddin olarak geçen kişi olabilir mi? Bu biraz zor görünüyor. Çünkü, aşağıda sekizinci sırada hakkında bilgi verdiğimiz ve $1525-1526$ tarihli defterde belirtilen "cemaat-ı mi"mârân"a kayıtlı mimarlar arasında yedinci sırada yer alan Alâeddin adlı bir başka mimar daha bulunmaktadır. Bu nedenle Rıfkı Melûl Meriç'in bahsettiği Mimar Alâeddin'in bu Alâeddin olması kuvvetle muhtemeldir. Zirâ, 1511 yılında henüz "cemaat-ı mi'mârân" a giremeyen Mimar Alâeddin'in 1525 yılında bu teşkilâta dahil olarak belirli bir mevkie yükselmiş olabilir. Dolayısıyla Yakub-şah'dan sonra mimarbaşı olduğu kabul edilen Ali bin Abdullah'ın ${ }^{10}, 1525-1527$ yıllarına ait kayıtlarda Mimarbaşı Alâeddin olarak geçen kişi olması kuvvetle muhtemeldir.

${ }^{2}$ Topkapı Sarayı Müzesi Arşivi (TSMA), D. 9706/2, s.2B

${ }^{3}$ Başbakanlık Osmanlı Arşivi (BOA), Maliyeden Müdevver Defterler (MAD), Numarası (nr.) 559, s.3.

TSMA, D. 9706/2, s.2B.

${ }^{5}$ Bkz. BOA, MAD, nr. 559, s.3, 23, 34, 43, 83, 123, 143, 163, 183, 203, 235, 251, 271, 291.

'Yakub-şah hakkında geniş bilgi için bkz. Rıfkı Melûl Meriç, "Beyazıd Câmii Mimârı II. Sultan Bayezıd Devri Mimarları Ile Bazı Binalan Beyazıd Câmii İle Alâkalı Hususlar, San'atkârlar ve Eserleri”, Yıllık Araşurmalar Dergisi II, Ajans-Türk Matbaası, Ankara 1958, s.28-30.

${ }^{7}$ Bkz. Merif̧, a.g. m, s.31.

${ }^{8}$ Bkz.Fatih Müderrisoğlu, 16.Yüzyılda Osmanlı Imparatorluğu'nda Inşâ Edilen Menzil Külliyeleri, (H.Ü.Sos.Bilim.Ens. Basılmamış Doktora tezi), Cilt.1, Ankara Ekim, 1993, s.110-115.

${ }^{9}$ Bkz. Meriç, a.g.m, s. 41 .

${ }^{10}$ Ali bin Abdullah hakkında geniş bilgi için bkz. Meriç, a. g. m, s.30-32. 


\section{2-ALI NECCAR}

Sultan II. Bayezid dönemi mimarları arasında da yer alan Ali Neccar" , 932/1525-1526 tarihli defterde de "cemaat-ı mi'mârân"/2 a kayıtlıdır. Günlük 23 akçe aylık ise 678 akçe ücret almıştır. ${ }^{13}$ Ali Neccar'ın günlük ve aylık olarak aldığ bu ücretten dönemin Hassa mimarlar ${ }^{14}$ içerisinde en tecrübeli üstad bir mimar olduğu anlaşılmaktadır. Çünkü bu defterde cemaat-ı mi’mârândan oldukları belirtilen 17 kişiden sadece Ali Neccar'a günlük ve aylık olarak bu yüksek ücretler verilmiştir..$^{15}$ Ayrıca cemaat-ı mi'mârândan oldukları belirtilen mimarlar bu deftere, almış oldukları ücretlerine ve deneyimlerine göre kaydedilmişlerdir. ${ }^{16}$ Cemaat-1 mi'mârânın deftere kaydedilmesinde izlenilen bu metottan, mimarlar arasında hiyerarşik bir yapının olduğu anlaşılmaktadır. Bu yapıya göre, 1525-1526 yılındaki 17 Hassa mimarından ilk sırada Ali Neccar yer almaktadır. ${ }^{17}$ Dolayısıyla Ali Neccar, Mimarbaşı Alaaddin'den sonra gelen ikinci mimardır. Ali Neccar'ın 1525-1526 yıllarında almış olduğu bu ücretin, 1533-1534 ve 1537 yıllarında da aynı olduğu, bu yıllara ait cemaat-ı mi'mârân'a bağlı mimarların ve aldıkları ücretlerin belirtildiği kayıtlardan anlaşılmaktadır. ${ }^{18}$

\section{3-MIMMAR MAHMUD}

Sultan II. Bayezid dönemi mimarlarından Mimar Mahmud ${ }^{19}$ da, 932/1525-1526 tarihli defterde "cemaat-ı mi'mârân" a kayıtlıdır. Günlük 22 akçe aylık ise 648 akçe ücret almıştır. ${ }^{20}$ Mahmud'a günlük ve aylık olarak ödenen bu ücretten onun, cemaat-1 mi'mârân içerisinde Ali Neccar'dan sonra en tecrübeli mimarlardan ve ikinci adam olduğu anlaşılmaktadır. ${ }^{21}$

"Bkz. Meriç, a.g.m, s.41.

12 Hassa Mimarlar Teşkilâtı hakkında detaylı bilgi için bkz.Orhan Erdenen, "Osmanlı Devri Mimarları, Yardımcıları ve Teşkilâtlan", Mimarlık, 4. Yıl, Sayı: 27, Ócak 1996, s.15-18; "Osmanlılarda Mimarlık Teşkilâtı", Hayat Tarih Mecmuası, Il/12 (İstanbul 1967), s.47-50; Abdulkadir Dündar, Arsivlerdeki Plân ve Cizimler Işı̆̆t Altında Osmanlt İmar Sistemi (XVIII. ve XIX. Yüzvil), Kültür Bakanlığı Yayınlanı /2480, Ankara 2000, s.7-73. Zeki Sönmez, "Mimar Sinan ve Hassa Mimarlar Ocă̆l", Mimar Sinan Dönemi. Türk Mimarlĭğ ve Sanatı, (Haz: Zeki Sönmez), İstanbul 1988, s.251-258.

${ }^{13}$ TSMA, D $9706 / 2$, s.10A.

${ }^{4}$ Hassa Mimarları hakkında bkz. Abdulkadir Dündar, "Osmanlı Mimarisinde Hassa Mimarları", Dinî Arastırmalar, Osmanlı Ozel Sayısı, Cilt: 2, Sayı: 5, Eylül- Aralık 1999, s.159-176; Zarif Orgun, "Hassa Mimarları", Arkitekt, Cumhuriyet Matbaas1, İstanbul 1939, s. 3-12; Serafettin Turan,"Osmanlı̣ Teşkilâtında Hassa Mimarları", Tarih Arasttrmalari Dergisi, Cilt: 1, Sayı: 1, Ankara Universitesi Basımevi 1964, s.157-202; Erhan Afyoncu, "XVI. Yüzyılda Hassa Mimarları", Prof. Dr. İsmail Aka Armağan,, İzmir 1999, s. 207-215.

Is TSMA, D. $9706 / 2$, s.10A.

16 TSMA, D. $9706 / 2$, s. 10A

${ }^{17} \mathrm{Bkz}$. TSMA, D. 9706/2, s.10A.

${ }^{18}$ Bkz. BOA, Kựuúk Rûznâmçe Kalemi (D. KRZ), Numarası (nr.) 33118, s.15; BOA, MAD, nr. 559, s. 282; Afyoncu, a. g. m, s.211-212.

${ }^{19}$ Bkz. Meric, a.g. m, s.41.

TSMA, D. $9706 / 2$, s.10A

${ }^{21}$ TSMA, D. $9706 / 2$, s.10A. 


\section{4-MIMMAR BÂLİ}

Sultan II. Bayezid dönemi mimarları arasında Hızır Bâli olarak geçen Mimar Bâli, 926/1519 yılından önce meremmetçilik ve su-yolculuk ${ }^{22}$ görevlerinde de bulunmuştur. ${ }^{23}$ 932/1525-1526 yıllarında "cemaat-ı mi'mârân" a kayıtlı olduğu anlaşılan Mimar Bâli'nin günlük 21 akçe aylık ise 619 akçe ücret aldığı görülmektedir. ${ }^{24}$ Aldığı bu ücretlerle Mimar Bâli, 1525 yılındaki cemaat-ı mi’mârâna bağlı mimarlar arasında ưçuincủ sırada yer almıştır. ${ }^{25}$

\section{5-MIMMAR HÜDAVERDi}

Sultan II. Bayezid dönemi mimarları içerisinde yer alan Mimar Hüdaverdi, İstanbul Bayezid Câmii mimarı ve mimarbaşı Yakub-şah'ın oğludur. ${ }^{26}$ Ismi 932/1525-1526 tarihli defterde de "cemaat-ı mi'mârân" arasında geçen Mimar Hüdaverdi günlük 18 akçe aylık ise 531 akçe ücret almıştır. ${ }^{27}$ Defterdeki "Edirne'den alır" şeklindeki kayıttan, Mimar Hüdaverdi'nin ücretini Edirne'den aldığı anlaşılmaktadır. ${ }^{28}$ Aldığı bu ücretle Mimar Hüdaverdi, 1525 yılındaki cemaat-1 mi'mârâna bağlı mimarlar arasında dördüncü sırada yer almaktadır. ${ }^{29}$

\section{6-MIMAR SÜLEYMAN}

Sultan II. Bayezid dönemi mimarları arasında ismine rastlanılmayan ${ }^{30}$ Mimar Süleyman 932/1525-1526 tarihli defterde "cemaat-ı mi"mârân" a kayıtlıdır. Günlük 13 akçe aylık ise 383 akçe ücret almıştr. ${ }^{31}$ Mimar Şeyhi ile aynı maaşı aldığı halde, muhtemelen tecrübe ve deneyimi göz önünde bulundurularak, cemaat-ı mi'mârânın sıralamasında Şeyhi'nin uistünde beşinci sırada yer almaktadır.$^{32}$ Bazı kayıtlardan Mimar Süleyman'ın 1533-1534 ve 1537 yıllarında da aynı ücreti aldığ $1^{33}$ ve Zilkade 943 / Nisan 1537 tarihli ulûfesiyle ilgili bir başka kayıttaki bilgilerden ise vefat ettiği anlaşılmaktadır. ${ }^{34}$

\section{7-MIMAR ŞEYHİ}

Sultan II. Bayezid döneminde "cemaat-ı mi"mârân" arasında yer almayan fakat o dönemin mimarlarından sayılan Mimar Şeyhi'nin ${ }^{35}$, 932/1525-1526 tarihli defterde "cemaat-ı mi'mârân"a kayıtlı olduğu anlaşılmaktadır. Günlük 13 akçe aylık ise 383 akçe ücret almıştır. ${ }^{36}$ Mimar Süleyman ile aynı maaşı aldığı halde,

${ }^{22}$ Su-yolculuk hakkında geniş bilgi için bkz. Abdullah Martal, "16. Yüzyılda Osmanlı Imparatorluğuda Su-Yolculuk”, Belleten, LII/205 (1988), s.1585-1653.

${ }^{23}$ Bkz. Meriç, a. g. m, s.41.

${ }^{24}$ TSMA, D. $9706 / 2$, s.10A

${ }^{25}$ TSMA, D. $9706 / 2$, s.10A

${ }^{26}$ Bkz. Meriç, a. g. m, s.41.

${ }^{27}$ TSMA, D. $9706 / 2$, s.10A

${ }^{28}$ TSMA, D. $9706 / 2$, s.10A

${ }^{29}$ TSMA, D. $9706 / 2$, S.10A.

${ }^{30}$ Bkz. Meriç, a.g. m, s.41.

31 TSMA, D. $9706 / 2$, s.10A

${ }^{32}$ TSMA, D. 9706/2, s.10A.

${ }^{33}$ Bkz. BOA, D. KRZ, nr. 33118, s. 15; BOA, MAD, nr. 559, s.282

${ }_{34}^{34} \mathrm{Bkz}$. BOA, MAD, nr. 559, s.300; Afyoncu, a.g.m, s.212.

${ }^{35}$ Meriç, a. g. m. s. 41.

${ }^{36}$ TSMA, D. $9706 / 2$, s.10A 
muhtemelen tecrübe ve deneyimi göz önünde bulundurularak, cemaat-ı mi'mârânın sıralamasında Mimar Süleyman'ın altında altıncı sırada yer almıştır. ${ }^{37}$

\section{8-MİMAR ALÂEDDIN}

Mimar Alâeddin de, Sultan II. Bayezid döneminde "cemaat-t mi'mârân" a kayıtlı olmayıp o dönemde mimar olan kişiler arasındadır. ${ }^{38}$ Mimar Alâeddin 932/1525-1526 tarihli defterde ise "cemaat-ı mi'mârân" a kayıtlıđır. Günlük 12 akçe aylık ise 354 akçe ücret almıştır. ${ }^{39}$ Mimar Alâeddin'in aldığı bu ücretlerle 1525-1526 yıllarında Hassa mimarları arasında yedinci sırada bulunduğu anlaşılmaktadır. ${ }^{\text {th }} \mathrm{Bir}$ kayıtta Alâeddin Balâtî olarak da zikredilen Mimar Alâeddin 1533-1534 ve 1537 yıllarında da aynı ücretle çalışmıştır. ${ }^{41}$

\section{9-MIMAR DERVIŞ̧ ALi}

Sultan II. Bayezid döneminde de "cemaat-ı mi'mârân" a kayıtlı olan Mimar Derviş Ali'nin ${ }^{42}$, 932/1525-1526 tarihli defterdeki bilgilerden günlük 11 akçe aylık ise 321 akçe ücret aldığı anlaşılmaktadır. ${ }^{43}$ Aldığı bu ücretlerle Derviş Ali, 1525 1526 yıllarında Hassa mimarları arasında sekizinci sırada yer almaktadır.

\section{0-MİMAR YUSUF}

Mimar Yusuf 932/1525-1526 tarihli defterde "cemaat-ı mi'mârân" a kayıtlıdır. Günlük 9 akçe aylık ise 265 akçe ücret almıştır. "Ali Eflâk ile aynı maaşı aldığ halde, muhtemelen tecrübe ve deneyimi göz önünde bulundurularak, cemaat-1 mi'mârânın sıralamasında onun uistünde dokuzuncu sırada yer almaktadır ${ }^{45} \mathrm{Bu}$ mimar Yusuf ile Sultan II. Bayezid dönemi mimarlarından ve İstanbul Bayezid Câmii halifelerinden Yusuf bin Papas'ın aynı kişi olmadı̆̆ı anlaşılmaktadır ${ }^{46}$ Çünkü, o dönemde Ali bin Abdullah'dan sonra ikinci halife olan tecrübeli bir mimarın daha üst bir kademeye çıkması beklenirken, 1525 yılında "cemaat-ı mi'mârân" a kayıth mimarlar arasında dokuzuncu sırada gösterilmesi ve diğer mimarlara göre daha düşük ücret alması düşünülemez.

\section{1-ALİ EFLÂK}

Ali Eflâk'ın ismi de 932/1525-1526 tarihli defterde "cemaat-ı mi'mârân" arasında geçmektedir. Günlük 9 akçe aylık ise 265 akçe ücret almıştır. ${ }^{47}$ Mimar Yusuf ile aynı maaşı almaktaydı. Ancak, muhtemelen tecrübe ve deneyimi göz önünde bulundurularak, cemaat-ı mi'mârâna bağlı mimarların sıralamasında Mimar

\footnotetext{
${ }^{37}$ TSMA, D. 9706/2, s.10A.

${ }^{38}$ Bkz. Meric, a. g. m, s. 41 .

39 TSMA, D. $9706 / 2$, s. $10 \mathrm{~A}$

40 TSMA, D. $9706 / 2$, s.10A

${ }^{41} \mathrm{Bkz}$. BOA, D. KRZ, nr. 33118, s. 15; BOA, MAD, nr. 559, s. 282

${ }^{42}$ Bkz. Meric, a. g. m, s.41

43 TSMA, D. $9706 / 2$, s.10A

${ }^{44}$ TSMA, D. 9706/2, s.10A

45 TSMA, D. 9706/2, s.10A.

4h Yusuf bin Papas hakkında geniş bilgi için bkz. Meriç, a. g. m, s.26, 32

${ }^{47}$ TSMA, D. 9706/2. s.10A. Åyrica bkz. Meriç, a.g.m, s.27.
} 
Yusuf'un altında onuncu sırada yer almıştır. ${ }^{48}$ Bir kayıtta Ali Eflâk'ın 1533-1534 yıllarında da aynı ücreti aldığı görülmektedir. ${ }^{49}$

\section{2-ALİ BÍN SÜLEYMAN}

Ali bin Süleyman, 932/1525-1526 tarihli defterde "cemaat-t mi'mârân" a kayıtlıdır. Günlük 8 akçe aylık ise 236 akçe ücret almıştır. ${ }^{\text {5n }}$ İshak Kiremidî, İbrahim Murad Halife ve Ali Küçük ile aynı maaşı aldığı halde, muhtemelen tecrübe ve deneyimi göz önünde bulundurularak, cemaat-ı mi'mârâna bağlı mimarların sıralamasında onların üstünde onbirinci sırada yer almıştır. ${ }^{51}$ Ali bin Süleyman 1533-1534 yıllarında da aynı ücreti almıştır. ${ }^{52}$

\section{3-ISSHAK KİREMIDÎ}

İshak Kiremidî'nin ismi de 932/1525-1526 tarihli defterde "cemaat-ı mi'mârân" arasında geçmektedir. Günliik 8 akçe aylık ise 236 akçe uicret almıştır. ${ }^{53}$ İshak Kiremidî, Ali bin Süleyman, İbrahim Murad Halife ve Ali Küçük ile aynı maaşı aldığı halde, cemaat-ı mi'mârâna bağlı mimarların sıralamasında Ali bin Süleyman'ın altında, İbrahim Murad Halife ve Ali Küçük'ün üstünde onikinci sırada yer almıştır..$^{54}$

\section{4-IBBRAHIM MURAD HALİE}

İbrahim Murad Halife, 932/1525-1526 tarihli defterde "cemaat-l mi'mârân" a kayıtlıdır. Günlük 8 akçe aylık ise 236 akçe ücret almıştır. ${ }^{55}$ Ali bin Süleyman, İshak Kiremidî ve Ali Küçük ile aynı maaşı aldı̆̆ı halde cemaat-ı mi'mârâna bağlı mimarların sıralamasında Ali bin Süleyman ve İshak Kiremidî'nin alında Ali Küçük'ün ise üstünde onüçüncü sırada yer almaktadır. ${ }^{56}$

\section{5-ALİ KüÇÜK}

Ali Küçük de 932/1525-1526 tarihli defterde "cemaat-ı mi'mârân" a bağlı mimarlar arasındadır. Günlük 8 akçe aylık ise 236 akçe uicret almıştır. ${ }^{57}$ Ali bin Süleyman, İshak Kiremidî ve İbrahim Murad Halife ile aynı maaşı aldığı halde cemaat-ı mi’mârâna bağlı mimarların sıralamasında ondördüncü sırada yer almaktadır ${ }^{58}$ Ali Küçük 1533-1534 ve 1537 yıllarında da aynı günlük ve aylık ücreti almıştır. ${ }^{59}$

\footnotetext{
${ }^{48}$ TSMA, D. $9706 / 2$, s.10A.

${ }^{49}$ BOA, D. KRZ. nr. 33118, s.15.

Sn TSMA. D. 9706/2, s.10A.

S1 TSMA, D. 9706/2, s.10A.

${ }^{52}$ Bkz. BOA, D. KRZ, nr. 33118, s. 15.

${ }^{53}$ TSMA, D. 9706/2, s.10A.

54 TSMA, D. 9706/2, s.10A.

ss TSMA, D. 9706/2, s.10A.

${ }^{56}$ TSMA, D. $9706 / 2$, S.10A.

${ }^{57}$ TSMA, D. 9706/2, s.10A.

${ }^{58}$ TSMA, D. 9706/2, s.10A.

${ }^{54}$ Bkz. BOA, D. KRZ, nr. 33118 , s.15; BOA, MAD, nr. 559, s. 282
} 


\section{6-MIMMAR HIZIR}

Mimar Hizır'ın 932/1525-1526 tarihli defterdeki bilgilerden "cemaat-l mi"mârân" a bağlı mimarlardan olduğu anlaşılmaktadır. Aynı bilgilere göre Mimar Hızır günlük 7 akçe aylık ise 207 akçe ücret almışır. ${ }^{60}$ Mimar Hızır, Mimar Seydi ve Mustafa bin Şuca ile aynı ücreti aldığı halde cemaat-1 mi'mârâna bağlı mimarların sıralamasında onbeşinci sırada yer almaktadır ${ }^{61}$ Mimar Hızır 1533-1534 yıllarında da aynı ücreti almıştı..$^{62}$

\section{7-MIMMAR SEYDí}

Mimar Seydi de 932/1525-1526 tarihli defterde "cemaat-ı mi'mârân" a kayıtııdır. Günlük 7 akçe aylık ise 207 akçe ücret almışur ${ }^{63}$ Mimar Seydi, Mimar Hızır ve Mustafa bin Şüca ile aynı ücreti aldığı halde cemaat-ı mi'mârâna bağlı mimarların sıralamasında Mimar Hızır'ın altında Mustafa bin Şüca'nın ise üstünde onaltıncı sırada yer almaktadır. ${ }^{64}$ Mimar Seydî 1533-1534 yıllarında da günlük ve aylık olarak aynı ücreti almıştır. ${ }^{6.5}$

\section{8-MUSTAFA BİN ŞÜCA}

Mustafa bin Şüca, 932/1525-1526 tarihli defterde "cemaat-ı mi"mârân"a kayıtıdır. Günlük 7 akçe aylık ise 207 akçe ücret almıştır. ${ }^{6 / 6}$ Mustafa bin Şüca, Mimar Hızır ve Mimar Seydi ile aynı ücreti aldığı halde cemaat-ı mi'mârâna bağlı mimarların sıralamasında onların altında en sonuncu sıra olan onyedinci sırada yer almıştır. ${ }^{67}$

\section{9-YUSUF BOSNA}

Hassa Mimarlar Teşkilâtı'na bağlı mimarların isimleri ile günlük ve aylık olarak aldıkları ücretlerin zikredildiği kayıtlardan Yusuf Bosna'nın 1533-1534 ve 1537 yıllannda yevmî 14 aylık ise 413 akçe ücret aldığı anlaşılmaktadır. ${ }^{68}$

\section{0-DİMİTRİ VELED-i TODOROS}

Cemaat-1 mi'mârân'a bağlı mimarlar ve aldıkları ücretlerin belirtildiği kayitlarda Dimitri Veled-i Todoros'un 1533-1534 ve 1537 yillarında günlük 20 aylık ise 570 akçe ücret aldığı görülmektedir. ${ }^{69}$

\section{1-PORTEKIZLII KAPTAN FRANÇEŞKO}

Hassa Mimarlar Cemaatı'na bağlı mimarların isimleri ve aldıkları ücretlerin belirtildiği kayıtlardan Kaptan Françeşko'nun 1533-1534 yıllarında yevmî 50 aylık

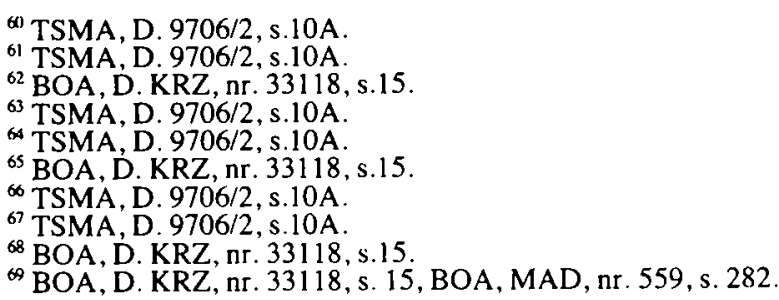


ise 1475 akçe ücret aldığı anlaşılmaktadır. ${ }^{70}$ Ayrıca, Kaptan Françesko'nun ulûfesine 16 Rebiyülahir 943/2 Ekim 1536 tarihinde 10 akçe zam yapılarak 50 akçeden 60 akçeye çıkarılmıştır." Böylece Kaptan Frasçeşko'nun aldığı uicret, dönemin mimarbaşısı Alâeddin'in ücretini geçmiştir.

\section{2-MIMAR ANTON}

Mimar Anton Zilhicce 942/Mayıs 1536 tarihinde yevmî 12 akçe aylık ise 354 akçe ücretle cemaat-1 mi'mârâna dahil edilmiştir. ${ }^{72}$ Mimar Anton'un aldığı bu ücretlerin Muharrem 955/ Şubat 1548 tarihinde yevmî 18 akçeye aylık ise 531 akçeye yükseldiği görülmektedir. ${ }^{73}$

\section{3- MIMAR HAYREDDIN}

Mimar Hayreddin'in ${ }^{74}$ adına Zilhicce 942/Mayıs 1536 tarihinde günlük 13 akçe aylık ise 383 akçe ücretle Hassa Mimarlar Ocağı'na dahil edildiği bir kayıtta "Mermeri $\hat{\imath}^{75}$ Hayreddin" şeklinde rastlanılmaktadır ${ }^{76}$ Mermerî Hayreddin'in aldığ bu ücreti Muharrem 955/ Şubat 1548 tarihinde yevmî 15 akçeye aylık ise 442 akçeye yükseltilmiştir. ${ }^{77}$ Mimar Hayreddin'in Ayaş'ta Kızlarağası Hamamı'nı inşa ettiği, 971/1563 yılında da Koca Mustafa Paşa evkafından münhedim bostan duvarlarının tamir keşfini Mimar Sinan ile birlikte yaptığı belirtilmektedir. ${ }^{78}$

Kayıtlardaki bilgilerden Mimar Hayreddin'in 975/1567-1568 yıllarında eyalet merkezi olan Üsküb'te ${ }^{79}$ ikâmet ettiği anlaşılmaktadır. Üsküb'de Hayreddin'den başka Memiş ve Yusuf adlı iki mimar daha bulunmaktaydı. Ayrıca Hayreddin'in "Mimarbaşı" unvanını taşıdığı görülmektedir. ${ }^{80}$ Yukarıda belirtilen yıllarda Osmanlı devletinin mimarbaşısı Mimar Sinan olduğuna göre büyük bir ihtimalle Hayreddin Üsküb'ün bağlı bulunduğu Kosova eyaletinin ${ }^{81}$ mimarbaşısıdır. $^{82}$ Mimarbaşı

${ }^{70}$ BOA, D. KRZ, nr. 33118, s. 15; BOA, MAD, nr. 559, s.282.

7 BOA, MAD, nr. 559, s. 173; Afyoncu, a. g. m, s.212.

${ }^{72} \mathrm{Bkz}$. BOA, MAD, nr. 559, s. 113 , s. 282; Afyoncu, a. g.m, s.212.

${ }^{73} \mathrm{Bkz}$. BOA, MAD, nr. 7118 , s. 12 .

${ }^{74}$ Mermerî Mimar Hayreddin ile Sultan II. Bayezid dönemindeki Mimar Hayreddin aynı kişi değildir. Çünkü, Rıfkı Melûl Meriç in de belirttiği gibi, büyük bir ihtimalle Mimar Hayreddin 1525 yilında vefat ettiginden ismi, $1525-1526$ yillarındaki "cemaat-l mi'mârân"a kayıtlı mimarlar arasında yer almamaktadır (Bkz. Meriç, a. g. m., s. 27 28).

75 Mimarlık farklı alanlarda yürütülen bir faaliyettir. Bu nedenle, Osmanlı dönemi mimarlık tarihinde, gemilerin yapımı ile ugraşan kimselere Gemi Miman, suyun nakli, bir başka yere akıtılması ve su getirmek gibi işlerle uğraşıp da ihtisaslaşan kimselere Su Mimarı, köprü yapımında uzmanlaşanlara Köprü Mimarı denildiği görülmektedir. Ayrıca, Osmanlı mimarlık faaliyetlerinde mimarların yetenekleri, kaabiliyetleri ve uzmanlık alanlan dikkate alınarak bir iş taksimine gidildiği ve bu sebeple bazı Hassa mimarlarının mermerî, minareci ve buna benzer bazı unvanlarla anıldıkları görülmektedir (Bkz. Dündar, "Osmanlı Mimarisinde Hassa Mimarlari", s.160-161).

76 Bkz. BOA, MAD, nr. 559, s. 113, s. 282; Afyoncu, a. g.m, s.212.

7 Bkz. BOA, MAD, nr. 7118 , s. 12 .

${ }_{78}^{78}$ Bkz. Orgun, a.g.m., s.6; Meriç, a. g. m., s.28, dipnot:29d.

79 Nazif Hoca, "Usküb", Islâm Ansiklopedisi, Cilt:13, Milli Eğitim Basımevi, Istanbul 1986, s.122-127.

${ }^{80}$ BOA, MD, nr. 7, sira: 1139 , s.397.

81 M. Münir Aktepe, "Kosova", Islâm Ansiklopedisi, Cilt: 6-2, Maarif Basımevi, İstanbul 1954, s.869-876. 
Hayreddin, 25 Ramazan 975 / 25 Mart 1568 tarihinde Üsküb kadısına gönderilen bir hükümle İstanbul'a çağrılmıştır. ${ }^{83}$

Aşağıda tam metnini verdiğimiz 9 Şevval 975/7 Nisan 1568 tarihli bir hükümden Mostar Köprüsü'nü Mimar Hayreddin'in yaptığı anlaşılmaktadır. ${ }^{84}$ Böylece bu kayıtla, bazı kaynaklarda mimarının mahalli bir mimar olduğu ileri sürülen $^{85}$ veya mimarına hiç değinilmeyen ${ }^{86}$, Mostar Köprüsü'nü Mimar Hayreddin'in inşa ettiği kesinlik kazanmaktadır. Yazılı kaynaklar ve üzerindeki kitâbeden köprünün inşasının 1566-1567 yıllarında tamamlandığı anlaşılmaktadır. Buna göre Mimar Hayreddin Kosova eyaletinde yaklaşık bir sene daha kaldıktan sonra 25 Mart 1568 tarihinde İstanbul'a çă̆rılmıştır. Yaklaşık 13 gün sonra Mimar Hayreddin yukarıda belirttiğimiz 7 Nisan 1568 tarihli hükümle Makarska İskelesi'nde inşâ edilmesi ferman buyurulan kalenin yapımı ile görevlendirilmiştir.

\section{4-SEMOR}

Mimar Semor'un ismi, baş tarafı eksik olan 950/1543 yılına ait bir müfredat defterinde geçmektedir. ${ }^{87}$ Defter eksik olduğu için hangi eserin inşasında çalışanlara ait olduğu kesin olarak tespit edilememiştir. Ancak deftere ait fişte, Şehzade Camii inşasının 956/1549 yılında tamamlanmıs olduğu belirtilerek, defterin muhtemelen bu câminin inşasında çalışanlara ait olabileceği ileri sürülmektedir. Bu defterdeki kayıtlara göre mimar Semor ismi kesin olarak bilinemeyen bir eserin inşaşında, 950 / 1543 yılının Rebiyülevvel / Haziran,Rebiyülahir / Temmuz, Cemaziyelevvel / Ağustos ve Cemaziyelahir / Eylül aylarında yevmiyesi 13 akçeden çalışmıştır. ${ }^{88}$

\section{5-YANİ}

Kayıtlardaki bilgilere göre Mimar Yani, İstanbul'da inşâ edileceği belirtilen İmaret-i Cedid ${ }^{89}$ için 27 Muharrem 951 / 16 Nisan 1544 tarihinde Aynöz'de küfeki taşı kestirmekle görevlendirilmiştir. ${ }^{(x)} \mathrm{Bu}$ görevi süresince Mimar Yani’ye Aynöz

${ }^{82}$ Cengiz Orhonlu, "Şehir Mimarları", Osmanlı Araştırmaları II, İstanbul 1981, s.15.

${ }^{83}$ BOA, MD, nr. 7, sira: 1139, s.397.

${ }^{84}$ BOA, MD, nr. 7, sira: 1216, s.423. "Mimarbassına hüküm ki:

Hersek Beği Hüseyin dâme ızzühû Südde-i Sa'ádetüm'e mektûb gönderup; “Makarska Iskelesi'nde binâ olunmak Fermân olunan kal'a binâstyçün mi'mâr lâzım olup ve bundan akdem Mostar Köprisi'n binâ iden Hayreddîn içün binâ ilminde mahâreti olup kala-i mezbûre binâsına mi mâr ta'yîn olunup gönderilmesin" arzeylemeğin buyurdum ki: Vusul buldukda, mezkâr Hayreddîn'i kal'a-i mezbûre binâsıy̧ün mi'mâr ta'yîn eyleyüp mu'accelen gönderesin ki, varup müsârun-ileyh vech ü münâsib gördüği üzre kal'a binasına mübaseret idüp itmâm-l maslahat eyleye"

${ }^{85}$ Bkz AnaBritannica. Cilt: 16, Istanbul 1989, s.253.

86 Bkz. Ekrem Hakki Ayverdi, Avrupa'da Osmanli Mimarî Eserleri Yugoslavya, II Cild, 3. Kitap, Baha Matbaası, İstanbul 1981, s.260-264.

8 TSMA, D.1801, s.1B.

TSMA, D.1801, s.7A, 8B, 9B,10B, 11B, 13A, 14B, 15B, 16B, 18B, 19A,20A.

\$o Kayıtta Imâret-i Cedid'in hangi külliye ya da yapı olduğu belirtilmemektedir. Ancak 16. Nisan 1544 tarihini göz önünde bulundurduğumuzda bu tarihte İstanbul'da iki külliyenin inşası devam etmekteydi. Bu külliyelerden biri Şch7ade diğeri ise Üsküdar Mihrimah Sultan külliyesidir. Dolayısıyla İmâret-i Cedid büyük bir ihtimalle bu iki külliyeden birisidir(Bu külliyeler hakkında bkz. Aptullah Kuran, Mimar Sinan, Hürriyet Vakfi Yayınları, İstanbul 1986, s. 48-64).

${ }^{*}$ BOA, Kamil Kepeci (KK), nr. 62. s. 60. 
Memlehası mahsulünden ödenmek üzere yevmî onbeş akçe ulûfe verilmesi kararlaştırılmıştır. ${ }^{91}$

\section{6-MIMAR KASIM}

Mimar Kasım Balyabadra'ya ${ }^{92}$ bağlı Burgaz,' Cedid Kalesi'ni tamir etmiştir. ${ }^{93}$ Ayrıca Mimar Kasım, bu kalenin tamirini henüz tamamlamadan kendisine 25 Muharrem 951/18 Nisan 1544 tarihinde "Mora sancă̆ı beyine ve kale-i Varna kadısina ve Balyabadra'ya tabi Burgaz-ı Cedid Kalesi'nin tamirine irsal olunan Kasım nam mimara hüküm yazıla ki" şeklinde başlayan bir hükümle, Varna Kalesi duvarlarının bazı yerlerini, kalenin yolunu, kale dizdarının oturduğu evleri, kalenin bazı kulelerini, kaledeki sarnıçları, bazı mahzenleri ve kaledeki câminin tamir edilmesiyle görevlendirilmiştir. ${ }^{94}$ Bu hükümde Mimar Kasım'ın kalede tamir edilecek yapıların "tahmin-i sahih ile" keşfini yapacağından bahsedilerek, kendisine şu tavsiyelerde bulunulmaktadır: "Ve sen ki mimarsin zikr olan hususatı tahmin ettiğin her vecihle tahmin edesiz ki ziyade harc lazım gelmeye sonra âdem gönderilüb tekrar tahmin ettirilmeye..." 95

Muharrem 955/ Şubat 1548 tarihli bir kayıtta adı Mermen̂́ Kasım olarak da geçen Mimar Kasım'ın 1548 yılında yevmî 8 akçe aylık ise 236 akçe ulûfe aldığı anlaşılmaktadır. ${ }^{\% 6}$

\section{7-MIMAR HIDAYET}

Kayıtlardaki bilgilerden cemaat-ı mi'mârâna bağlı mimarlardan olduğu anlaşılan Mimar Hidayet'in Muharrem 955-Receb 956/Şubat 1548-Temmuz 1549 tarihleri arasında günlük 22 akçe aylık ise 673 akçe ücret aldığ görülmektedir. ${ }^{97}$

\section{8-MIMMAR SIMMON}

Bazı kayıtlardaki bilgilere göre Hassa Mimarlar Cemaati'ne bağlı olan Mimar Simon Muharrem 955-Receb 956/Şubat 1548-Temmuz 1549 tarihleri arasında günlük 10 akçe aylık ise 290 akçe ücret almıştır. ${ }^{98}$

\section{9-MIMAR EMİN}

Bazı kayıtlardaki bilgilere göre cemaat-ı mi'mârân'dan olan Mimar Emin Muharrem 955-Receb 956/Şubat 1548-Temmuz 1549 tarihleri arasında günlük 33 akçe aylık ise 973 akçe ücret almıştır. ${ }^{99}$

\footnotetext{
${ }^{91}$ BOA, KK nr. 62, s. 60 .

92 Balyabadra: Mora yarım adasında müstahkem bir Osmanlı sehridir. 19, yüzyılın sonlarında Ahaya sancağının merkez jdaresi olub otuzbes bin nufusa sahipti. Yunanlılar bu şchre Patras veya Palyapatra derler (Bkz. Ahmed Rifat Efendi, Lügat-l Tarihiyye ve Coğrafiyye, Cilt: 1-2, Istanbul 1299, s.43).

${ }^{93} \mathrm{BOA}, \mathrm{KK}$ nr. 62, s. 79.

$94 \mathrm{BOA}, \mathrm{KK}$ nr. 62, s. 79.

${ }^{95} \mathrm{BOA}, \mathrm{KK}$ nr. 62, s. 79.

${ }^{96} \mathrm{Bkz}$. BOA, MAD, nr. 7118, s. 12

${ }^{97}$ Bkz. BOA, MAD, 7118, s. 12, 54, 82,118

${ }^{98}$ Bkz. BOA, MAD, 7118 , s. 12, $54,82,118$.

${ }^{9} \mathrm{Bkz}$. BOA. MAD, nr. 71 18, s. 12.55,82,118; Afyoncu, a. g. m, s.213.
} 


\section{0-MIMAR YORGi}

Hassa Mimarlar Ocağı'na bağlı mimarlardan olan Mimar Yorgi Muharrem 955-Receb 956/Şubat 1548-Temmuz 1549 tarihleri arasında günlük 8 akçe aylık ise 236 akçe ücret almıştır. ${ }^{100}$

\section{1-MIMMAR RÜSTEM}

Kayıtlardaki bilgilere göre cemaat-1 mi'mârân'dan olan Mimar Rüstem Muharrem 955-Receb 956/Şubat 1548-Temmuz 1549 tarihleri arasında günlük 12 akçe aylık ise 354 akçe ücret almıştır. ${ }^{101}$ Vefat ettiğinde Mimar Rüstem'in yerine 20 Şaban 963/29 Haziran 1556 tarihinde Mustafa bin Abdullah atanmıştır. ${ }^{102}$

\section{2-SELMAN}

Mimar Selman Van Eyaleti'nin mimarıdır. Rebiyülevvel 963/Ocak 1556 tarihli bir hükümde, Van beylerbeyinin mektup göndererek, Van Mimarlığı'nın daha önce yirmi akçe olduğu halde Selman adlı zimmiye onbeş akçeye verildiği belirtilir ${ }^{103}$ Selman'ın mimarlık ilminde mâhir ve çok yararlı olduğu ayrıca Van'da bulunan bütün mîrî binaların hizmetine koştuğu ve fazla emek sarfettiğinden verilen bu onbeş akçenin çok yetersiz olduğu belirtilerek, Mimar Selman'ın ulûfesinin 20 akçeye çıkarılması Divan'ı Hümayûn'a arz edilir. ${ }^{104}$

\section{3-AGUSTO}

Zimmî Agusto gemi mimarıdır. Ahtabolu'da inşa edilen gemilerin mimarlı̆̆ını yaptığı sırada bazı kimselerden usulsüz olarak para aldığı iddialan üzerine, 6 Şevval 973/26 Nisan 1566 tarihli bir hükümle görevinden alınarak yerine ismi belirtilmeyen başka bir mimar atanmıştır. ${ }^{105}$ Mimar Agusto'nun bundan sonraki faaliyetleri ve ölüm tarihi hakkında herhangi bir bilgiye rastlanılmamaktadır.

\section{4-MUSTAFA BİN ABDULLAH}

Mimarbaşı Sinan Divân-1 Hümâyûn'a mektup göndererek sefer mimarı Rüstem' in vefatı sebebiyle boşalan yerine üç akçe ile mermercilik hizmetinde çalışan Mustafa bin Abdullah'ın atanmasını teklif eder ve 20 Şaban 963/29 Haziran 1556 tarihinde bu atama gerçekleşir. ${ }^{106}$ Ancak Mustafa'ya ilk önce yevmi altı akçe verildiği halde sonraları bu ücreti dört akçeye düşürülmüş̧ür. Yukarıda da belirttiğgimiz gibi Mustafa bin Abdullah bu göreve atanmadan önce mermercilik görevini yürütmüş̧ür. Dolayısıyla bu bilgilerden, mimar Mustafa'nın mermercilik üzerine ihtisaslaşmı̧ olduğu anlaşılmaktadır. Mustafa bin Abdullah'ın bu mermercilik görevini, hangi câminin inşâsında yaptı̆̆ı kayıtta belirtilmemiştir. Ancak bu bilgilerin bulunduğu kaydın tarihi ve yerine getirilen Mustafa bin

\footnotetext{
${ }^{10 n}$ Bkz. BOA, MAD, nr. 7118, s. 12, 55, 82, 118; Afyoncu, a.g. m, s.213.

${ }^{101}$ Bkz. BOA, MAD, nr. 7118, s. 12, 55, 82, 118; Afyoncu, a. g. m, s.213.

${ }^{102}$ Bkz. BOA, MD, nr. 2, sira: 1037, s.101.

${ }_{103}$ BOA, Mühimme Defterleri(MD), nr. 2, sıra:13, s. 2.

ros BOA, MD, nr. 2, sira: 13, s. 2 .

tus 5 Numarahı Mühimme Defteri, Başbakanlık Devlet Arşivleri Genel Müdürlüğü Osmanlı Arşivi Daire Başkanlığı Yayınları / 21, Ankara 1994, sıra: 1477, s.228.

${ }^{1 * *}$ BOA, MD, nr. 2, sira:1037, s.101.
} 
Nebi'nin Süleymaniye Câmii halifelerinden olması, gerek Mustafa bin Abdullah'ın gerekse Mustafa bin Nebi'nin Süleymaniye Camii'nin inşâsında mermer işlerinden sorumlu olarak çahışan mimarlar olduklarına işaret etmektedir. ${ }^{107}$

\section{5-MUSTAFA BİN NEBİ}

Mustafa bin Nebi, devrin mimarbaşısı olan Mimar Sinan'ın Divân-ı Hümâyûn'a mektup gönderip, mermercilik hizmetine uygun olduğu teklifi üzerine 20 Şaban 963 / 29 Haziran 1556 tarihinde yevmî iki akçe ile bu göreve atanmıştır. ${ }^{108}$ Ayrıca kayıtta, Mustafa bin Nebi'nin inşası hâlâ devam eden câminin mimar halifelerinden olduğu belirtilmektedir. Ancak bu câminin hangi câmi olduğu hakkında bilgi verilmemiştir. Kanaatimizce bunun sebebi 1556 yılında inşası devam eden câminin Süleymaniye Câmii olduğunun bütün herkes tarafından bilinmesidir. Zaten bu konuyla ilgili iki kaydın tarihinin de 1556 yılına ait olması bunu teyit etmektedir.

Mermerci Mustafa bin Nebi, on akçe ile Hassa mimarı olan Salih Abdullah'ın vefatı üzerine Mimarbaşı Sinan'ın teklifiyle 16 Receb 968 / 2 Nisan 1561 tarihinde sekiz akçe ile onun yerine Hassa mimarı olarak atanmıştır. ${ }^{109}$

\section{6-HOCA CAN}

Erzurum Beylerbeyi Divân-ı Hümâyûn'a mektup göndererek, Erzurum'da bulunan kalelerin daima onarıma ihtiyaç duyduğunu, burada bir kale inşa etmek istediklerinde inşa işlerinden anlayan hazır bir mimarın bulunmadığından, mimari ile ilgili işlerin iyi gitmediğini ve bu zamana kadar ki mimar ihtiyacını ise Diyarbakır'dan karşıladıklarını belirtilerek, Erzurum'a bir mimar tayin edilmesini istemiştir. ${ }^{110}$ Bunun üzerine Divân-1 Hümâyûn 25 Muharrem 964/28 Kasım 1556 tarihli bir kararla, Mimar Hoca Can’a bir gönüllu gediği tevcih ederek, 8 akçe ulufe ile onu Erzurum Vilayeti'ne mimar olarak tayin etmiştir."

107 Süleymaniye Câmii'nin temelinde kullanılacak taşların çıkartılması amacıyla İmit'teki taş ocaklarına gönderilen fakat adları bclirtilmcyen iki mimardan bahsedilmektedir. Aydıncık'taki taş ocaklarında görevli kişiler arasında "mimara tâbi Hacı Hüseyin Halife" adlı bir başka mimarın adı geçmektedir. Ereğli'deki taş ocağı ile bu bölgedeki diğer ocaklarda ise taş çıkarmakla meşgul olan mimarlardan Hacı adında bir kişinin ismine rastlanılmaktadır (Bkz. Ömer L. Barkan, Süleymaniye Cami ve Imareti Inşautı (1550-1557), Cilt: 1, Türk Tarih Kurumu Basımevi, Ankara 1972, s.352, $353,355)$. Dolayısıyla Süleymaniye Câmii'nin mermercilik hizmetinde görev alan gerek Mustafa bin Abdullah ve gerekse Mustafa bin Nebi'nin taş ocaklarında çalıştıklarına dair her hangi bir kayda rastlanılmamaktadır. Ayrıca bu iki mimarın isimleri Ömer L. Barkan'ın Süleymaniye Külliyesi'nde çalışan müslüman sengtras ve neccarlar arasında da geçmemektedir (Bkz. Barkan, a. g. e, Cilt:1, s.194-232, 303-311, Cilt:2, s.78-100). Kanaatimizce bu iki mimar halifesinin, tas ocaklarında calışan mimarlar arasında isimlerinin geçmeme scbcbi, inşaatın başında görevli olmalarıdır. Mimarların adlarının gerek küllıyenin inşasında çalışanların arasında ve gerekse ödenen ücret kayıtlarında zikredilmeme nedeni ise mimarların ücretlerini Küçük Ruznâmçe Kalcmi'nden almarıdır (Bkz. Dündar, "Osmanlı Mimarisinde Hassa Mimarlan", s.173-174; Turan, a. g. m, s. 162-163).

${ }_{108} \mathrm{BOA}, \mathrm{MD}, \mathrm{nr} .2$, sira:1036, s.101.

${ }^{109}$ BOA, MD, nr. 4, sira:2109, s. 202.

${ }^{110}$ BOA, MD, nr. 2, sira: 1714, s. 187.

"I BOA, MD, nr. 2, sıra: 1714 , s. 187. 


\section{7-FERHAD}

Mimar Ferhad, Ali Paşa'nın Mezar-ı Şerif yakınlarındaki Saray ${ }^{112}$ şehrinde yaptırdığı câmi ve nehir kenarındaki seddin mimarıdır. ${ }^{113}$ Câmi ve seddin inşâsında çalışan usta ve ırgadlara verilen ücretlerle, bu yapılara harcanan taş, kireç, kiremid ve kurşun gibi malzemelerin kaydedilmiş olduğu 966/1559 tarihli defterde mimar Ferhad'ın, 3 Receb 966/11 Nisan 1559 tarihinden 18 Şevval 966/24 Temmuz 1559 tarihine kadar bazı günler yevmiyesi 13 akçe ile fakat çoğunlukla 15 akçe yevmiye ile çalıştı̆ı kayıtlıdır. ${ }^{1 / 4}$ Defterdeki bu bilgi, Mimar Ferhad'ın yaklaşık üç aylık bir çalışma süresine aittir. Dolayısıyla câmi ve seddin inşâsının üç ay gibi kısa bir süre içerisinde bitirilmiş olduğu düşünülemez. Bu sebeble defterin, câmi ve seddin inşâsına ait bütün bilgileri ihtiva etmediği anlaşılmaktadır.

\section{8-SALİH ABDULLAH}

Salih Abdullah günlük on akçe ile Hassa Mimarlar Ocağı'nda görev yapmıştır. 1561 yılında vefat edince yerine Mimarbaşı Sinan'ın Divân-ı Hümâyûn'a teklifiyle 16 Receb 968 / 2 Nisan 1561 tarihinde sekiz akçe ile mermerci Mustafa bin Nebi atanmıştır. ${ }^{.15}$

\section{9-FERHAD BIN ABDULLAH}

Ferhad bin Abdullah günlük yedi akçe ile Hassa mimarı olarak görev yapmıştır. Ancak hassa mimarlarından yukarıda belirtildıği gibi on akçe ile çalışan Salih Abdullah'ın vefatı üzerine ondan boşalan kadroya sekiz akçe ile mermerci Mustafa atanmış ve Salih Abdullah'dan kalan iki akçe ise Mimarbaşı Sinan'ın Divân-1 Hümâyûn'a teklifiyle Ferhad bin Abdullah'a verilerek ücreti 16 Receb 968 / 2 Nisan 1561 tarihinde dokuz akçeye çıkarılmıştır. ${ }^{116}$

\section{0-MURAD BİN ALİ}

Mermerci Mustafa bin Nebi'nin, Hassa mimarlarından Salih Abdullah'in yerine atanmasıyla boşalan yerine Mimarbaşı Sinan'in teklifi üzerine iki akçe ile 16 Receb 968 / 2 Nisan 1561 tarihinde Murad bin Ali atanmıştır. ${ }^{17}$ Kayıtlarda Murad bin Ali'nin bu görevden Hassa mimarlığına yükseltilip yükseltilmediğine dair herhangi bir bilgiye rastlanılmamaktadır.

112 Bu kayıtta geçen Saray Şehri'nin bugün neresi olduğunu tespit edemedik. Araştırmalarımıza göre, Mczar-1 Şerif adında Afganistan'dakinden başka bir şehir bulunmamaktadır ve kayıtta geçtiği gibi onun yakınlarında da Saray isimli bir şehir mevcut değildir. Ansiklopediler de ise Saray adlı önemli iki şehirden bahsedilmektedir. Biri Altin Ordu devletinin basssehri olan ve bugün sadece harabcleri bulunan Saray Sehri, diğeri ise Tekirdăg ili'ne bağlı bir ilçe merkezi olan Saray Sehri (Bkz. AnaBritannica, Cilt: 19, Istanbul 1990, s.93, Şemsettin Sami, Kâmûsu'l-A 'lâm, Cilt: 4, İstanbul 1314(1896). S.2546; Türk Ansiklopedisi, Cilt:28. Milli Eğitim Basımevi, Ankara 1980, s.152-153).

${ }_{113}^{13}$ TSMA, D.3902, s.1B.

11. TSMA, D.3902. s.IB, 2A-B, 4A-B. 5A-B, 7A, 8A-B, 9A.

115 BOA, MD, nr. 4. sira: 2109 , s.202.

${ }^{116} \mathrm{BOA}, \mathrm{MD}, \mathrm{nr} .4$. sira: 2109, s.202.

${ }^{17}$ BOA, MD, nr. 4, sira: 2109 , s.202. 


\section{1-MIMAR MEHMED}

Hassa mimarlarından olan Mimar Mehmed altı bin timara sahip bir mimardı..18 3 Rebiyülahir 971/20 Aralık 1563 tarihli bir kayıttaki bilgilerden, Karapınar Sultan Selım Câmii inşasının başlamasından sonuna kadar bu eserin yapımında çalış̧ı̆̆ anlaşılmaktadır ${ }^{119} \mathrm{Bu}$ câminin inşasının tamamlanmasından sonra, altı bin akçelik timarına dokuz bin akçe zam yapılarak timarı onbeş bin akçeye çıkarılmıştır. ${ }^{120}$ Böylece Mimar Mehmed, Karapınar Sultan Selim Câmii'nin yapımında gösterdiği üstün başarı nedeniyle dokuz bin akçelik timarla ödüllendirilmiştir.

Araştırmalarımızda Mimar Mehmed ile ilgili iki kayda daha rastladık. Birinci kayittaki bilgilerden Mimar Mehmed'in 21 Zilkade 980/25 Mart 1573 tarihinde Istanbul'da kaldırımcıların nazırlığını yaptığı anlaşılmaktadır ${ }^{121}$ İkinci kayıtta ise Mimar Mehmed'e, Saray-ı Amire'de inşa edildiği belirtilen Bimarhane'ye hizmetinden dolayı 24 Ramazan 992/26 Eylül 1584 tarihinde dört akçe zam verildiği zikredilmektedir. ${ }^{122}$ Böylece bu kayıtlar, Karapınar Sultan Selim Câmii'nin 15601563 yılları arasında inşâsında çalışan Mimar Mehmed'in 1584 yılına kadar hayatta olduğunu ve Hassa mimarı olarak çalışmalarına devam ettiğini göstermektedir.

\section{2-TODOR}

Hassa mimarlarından olan Todor yevmî yedi akçe ulûfe almaktaydı. Gülanber Kalesi'nin inşasıyla görevlendirilmişti. 25 Cemaziyelahir 971/ 19 Şubat 1564 tarihinde vefat ettiğinden yerine aynı ulûfe ile Mihayil tayin edilmiştir. Ancak Mihayil kalenin yapımına gitmemiştir. Mimarbaşı Sinan'ın isteği üzerine Mehmed oğlu Hayreddin oğlu Mehmed, Mihayil'in yerine Gülanber Kalesi'ni inşa etmek şartıyla atanmıştır. ${ }^{123}$

\section{3-MiHA YIL}

Mimar Sinan'ın "kâr-ı güzâr her vecihle hizmet-i edasına kâdir" şeklindeki sözleriyle övduğüu Mimar Mihayil, 1564 yılında Gülanber Kalesi'nin inşasıyla görevlendirilmiştir. Ancak Mihayil bu görevi kabul etmediğinden onun yerine, yukarıda da belirtildiği gibi Mehmed oğlu Hayreddin oğlu Mehmed atanmıştır. ${ }^{24}$

\section{4-MEHMED OĞLU HAYREDDIN OĞLU MEHMED}

Gülanber Kalesi'ni inşa etmek şartıyla 25 Cemaziyelahir 971/ 19 Şubat 1564 tarihinde Mihayil'in yerine günlük yedi akçe ulûfeyle Hassa mimarı olarak

${ }^{118}$ Mimar Mchmed hakkında detaylı bilgi için bkz. Abdulkadir Dündar, "Karapınar Sultan Selim Câmii'nin Mimarı Hakkında Yeni Bir Kayıt ve Bazı Mülahazalar",Türkiye Büyük Millet Meclisi'nin Açılışının 80. Yıldönümü, Karapınar Sempozyumu (26-27 Ekim 200), (Editör: Yusuf Küçükdağ), Konya- Karapinar Belediyesi Yayın No:4, Konya 2001, s. $165-174$.

${ }^{119}$ BOA. KK, Ru'ûs Kalemi (A. RSK), nr. 218, s. 80.

${ }^{120} \mathrm{BOA}, \mathrm{KK}, \mathrm{A} . \mathrm{RSK}, \mathrm{nr} .218, \mathrm{~s} .80$.

121 BOA, MD, nr. 21 , sira: 482 , s. 202.

122 BOA. KK, A.RSK, nr. 244, s.103. Kayıtta Mimar Mehmed dışında Saray-ı Amire'de bina olunan Bîmarhane'ye hizmet ettiği için Ahmed Reis'e de üç akçe terakkî verildiği belirtilmektedir.

${ }^{123}$ BOA, KK. A. RSK, nr. 218, s. 43

${ }^{124}$ BOA. KK. A. RSK, nr. 218, s.43. 
atanmıştır. ${ }^{125}$ Böylece Gülanber Kalesi'nin Mimar Mehmed oğlu Hayreddin oğlu Mehmed tarafında inşa edildiği anlaşılmaktadır. ${ }^{126}$

\section{5-MIMAR ABDULKADIR}

Mimar Abdulkadir Haleb'in Bahsita Mahallesi'nde ikâmet etmiş olup bir müddet Haleb taşctbaşıllığı görevinde bulunmuştur. ${ }^{127}$ Babası Nasruddin, Arafat'a gelecek su yolunun inşası için Şam'dan gönderilen taş ustalarının ustabaşısı tayin edilerek, 8 Şevval 973/28 Nisan 1566 tarihli bir hükümle Mekke'ye gönderilmiştir. ${ }^{128}$

\section{6-ÜSTAD BALI}

Su-yolu mimarı olan Üstad Bâli’den, 12 Rebiyülevvel 973 / 7 Ekim 1565 tarihli bir kararla, Sultan II. Bayezid'in Yoros Kalesi'nde yaptırdığı câminin yanındaki çeşmenin su-yolu ve kullesinin ${ }^{129}$ tamir edilmesi gereken örtüsünün onarım keşfini yapması istenmiştir. Üstad Bâli, su-yolcu Üstad Nasuh, kale dizdarı, kale kethüdası ve diğer ilgililerden oluşan bir heyet kurarak, çeşmenin su yolunun az masrafla tamir edilmesinin bir faydası olmayacağını, su yolunun yenilenmesiyle haznesi olan çeşmeye yeterli miktarda su getirilmesinin mümkün olduğunu, kullenin örtüsünün tamiri için beşbin örtü kiremidine ihtiyaç duyulduğunu ve bütün bu işlerin ikibin dört yüz üç akçeye mal olacağını tespit etmiştir. ${ }^{130}$

\section{7-MIMAR MEMIŞ}

Üsküb'de ikâmet eden Mimar Memiş'in kayıtlardaki bilgilerden Üsküb'de Mimarbaşı olan Hayreddin ile birlikte çalıştı̆̆ı veya onun emrindeki mimarlardan biri olduğu anlaşılmaktadır. ${ }^{131}$ Mimar Memiş de, Mimarbaşı Hayreddin ve Mimar Yusuf ile beraber, 25 Ramazan 975 / 25 Mart 1568 tarihinde Üsküb kadısına gönderilen bir hükümle İstanbul'a çağrılmıştır. ${ }^{132}$

\section{8-MIMAR YUSUF}

Mimar Yusuf, Üsküb'te Mimarbaşı Hayreddin ile birlikte çalışan mimarlardan biridir. 25 Ramazan 975 / 25 Mart 1568 tarihinde Mimarbaşı Hayreddin ve Mimar Memiş ile beraber İstanbul'a çağrnlmıştır. ${ }^{133}$

\footnotetext{
${ }^{125}$ BOA, KK. A. RSK, nr. 218, s.43.

${ }_{126}$ Bu kalenin inşasında calışmak üzere tayin edilen diğer usta ve görevliler hakkında geniş bilgi için bkz. BOA, KK. A. RSK, nr. 218. s.143-144.

iz 5 Numaralı Mühimme Defteri, sira:1492, s.544.

128 5 Numaralı Mühimme Defteri, sıra: 1492, s.544.

${ }^{129}$ Arapça'da küp, büyük küp ve testi anlamlarına gelen kulle ayrıca Arapların kullandıkları kapların genel adıdır(Bkz. İbn Manzûr, Lisanu'l-Arab, Cilt: II, Beyrut 1956, s. 565). Yukarıdaki bilgilerden ise kullenin muhtemelen su haznesi olduğu anlaşılmaktadır.

${ }^{130} \mathrm{BOA}, \mathrm{MAD}, \mathrm{nr} .2775$, s.365; Martal. a. g. m, s.1638-1639

${ }^{131}$ BOA.MD.nr. 7, sira: 1139 , s.397.

132 BOA, MD, nr. 7, sira: 1139. s.397.

${ }^{133}$ BOA, MD, nr. 7. sira: 1139, s.397.
} 


\section{9-COVAN SÜRMEYÜK}

Vezir Mustafa Paşa tarafından Kıbrıs'ta yakalanıp İstanbul'a gönderilecek esirlerin arasında Covan Sürmeyük adında bir de mimarın bulunduğu Divân-ı Hümâyûn'a bildirilir. Bunun üzerine Divân-1 Hümâyûn, 22 Zilhicce 978/17 Mayıs 1571 tarihli bir hükümle, faydalı insanlar oldukları belirtilen diğer esirlerle birlikte Mimar Covan'ın da İstanbul'a gönderilmesini istemiştir. ${ }^{134}$

\section{0-MİMAR AHMED BIN MAHMUD}

Kayitlardaki bilgilerden Mimar Ahmed bin Mahmud'ın Konya'nın Şerafeddin Mahallesi'nde ikâmet ettiği anlaşılmaktadır. Kıbrıs'ın fethi(1571)nden sonra Kıbrıs'ta yıkılan kalelerin tamiri ile görevlendirilmiştir. Ayrıca bu onarım için Ahmed bin Mahmud ile birlikte Naib ve Mülâzim Mevlânâ Şemseddin Halîfe'nin nezaretinde bennâ ve neccârlar da Kıbrıs'a gönderilmiştir..$^{135}$

\section{1-AHMED}

Mimar Ahmed Ayasofya Camii vakfının mimarıdır. 27 Zilhicce 979/11 Mayıs 1572 tarihli bir hükümde onun Meclis-i Şer’a giderek, bazı kişilerin Ayasofya Camii'nin duvarlarına ve avlusuna müdahalede bulunduklarını şikayet ettiği ve bu şikayet üzerine camiye yapılan bu müdahalenin boyutlarının, Naib Abdurrahman, Mehmed Çavuş ve ehli-i vukuftan oluşan bir heyetle tespit edildiği belirtilmektedir. ${ }^{136}$

\section{2-KARA HASAN}

Kara Hasan Edirne Selimiye Camii halifelerindendir. 979/1572 yılında bu camii için Marmara adasından çıkarılan mermer işinde çalışmışıır. ${ }^{137}$

\section{3-HÜSEYIN ABDULLAH}

Mimar Ağa' ya bağlı mimarlardan olduğu belirtilen Mimar Hüseyin Abdullah'a 18 Receb 982 / 4 Kasım 1573 tarihli bir hükümle hisar gediği verilmiştir. ${ }^{138}$

\section{4-MEHMED ABDULLAH}

Kayıtlardaki bilgilerden Hassa mimarı olduğu anlaşılan Mimar Mehmed Abdullah'a 18 Receb $982 / 4$ Kasım 1573 tarihli bir hükümle hisar gediği verilmiştir. ${ }^{139}$

\section{5-YUSUF ABDULLAH}

Hassa mimarlarından olan Yusuf Abdullah'a 18 Receb 982 / 4 Kasım 1573 tarihli bir kararla hisar gediği verilmiştir. ${ }^{100}$

\footnotetext{
134 I2 Numaralı Mühimme Defteri, I, Başbakanhk Devlet Arşivleri Genel Müdürlügüü Osmanlı Arşivi Daire Başkanlığı Yayınlar / 33, Ankara 1996, sıra: 511, s. 324.

${ }^{135}$ Konya Şer iye Sicili, nr.2, s.266; Yusuf Küçükdağ, Karapinar Sultan Selim Külliyesi, Karapınar Belediyesi Kültür Yayını no:3, Konya 1997, s.88, dipnot:204.

136 BOA, MD 16, sira: 375 , s. 194.

${ }^{137}$ BOA, MD, nr. 10, sira: 262 , s. 174.

138 BOA, MD, nr. 25, sira: 2879 , s.313.

${ }^{139}$ BOA, MD, nr. 25, sira: 2879, s.313.
} 


\section{6-HASAN ABDULLAH}

Mimar Ağa'ya bağlı mimarlardan olduğu belirtilen Mimar Hüseyin Abdullah'a 18 Receb 982 / 4 Kasım 1573 tarihli bir hükümle hisar gediği verilmiş̧ir. ${ }^{141}$

\section{7-HAMZA ABDULLAH}

Kayıtlardaki bilgilerden Hassa mimarlarından olduğu anlaşılan Hamza Abdullah'a 18 Receb 982 / 4 Kasım 1573 tarihli bir hükümle hisar gediği verilmiştir. ${ }^{142}$

\section{8-İSMAİL ABDULLAH}

Mimar Ağa'ya bağlı mimarlardan olduğu belirtilen mimar İsmail Abdullah'a 18 Receb 982 / 4 Kasım 1573 tarihli bir hükümle hisar gediği verilmiştir. ${ }^{143}$

\section{9- KOSTA}

Mimar Kosta Ayamavra Kalesi'ni inşa etmiştir. Kendisinden memnun olan Ayamavra kadısı Divân-ı Hümâyûn'a bir mektup göndererek Kosta'ya, bir akçelik terakki (zam) verilmesini istemiştir. Kadının bu isteğini olumlu karşılayan Divân-1 Hümâyûn mimar Kosta'ya 8 Zilkade 981/29 Şubat 1574 tarihinde bir akçelik terakki vermiştir. ${ }^{\text {44 }}$ Kayıtlarda Mimar Kosta'nın maaşının kaç akçe olduğu belirtilmemektedir.

\section{0-ABDULLAH İBRAHIM}

Bazı kayıtlardaki bilgilerden Abdullah İbrahim'in 1574 yılında su-yolu mimarı olduğu anlaşılmaktadır. ${ }^{145}$

\section{1-YANI}

Mimar Yani, 6 Ramazan $985 / 17$ Aralık 1577 tarihinde yedi akçe ulûfe ile Hassa mimarı olmuştur. Yani'nin Hassa mimarlı̆ğna atanmadan önce 10 akçe gediği olan fakat kayıtta ismi belirtilmeyen bir mimarın vefatı üzerine atamasının yapıldığı anlaşılmaktadır. ${ }^{146}$ Vefat eden bu mimardan geriye kalan dört akçelik gediğin ise Yani ile birlikte "Üsküdar'da Cami-i Serife hizmet eden mimarlardan dört nefere birer akçe" verildiği belirtilmektedir. ${ }^{177}$ Bu kayıttan Yani ile beraber Behram, Karec (?) ve Namiyeş (?) adhı bu mimarların ismi zikredilmeyen fakat Üsküdar'da olduğu belirtilen bir câminin inşasında çalış̧ıkları anlaşılmaktadır. ${ }^{148}$ Kayıtta ismi

\footnotetext{
${ }^{144)}$ BOA, MD, nr. 25, sira: 2879, s.313.

${ }^{141}$ BOA, MD, nr. 25, sira: 2879 , s.313

${ }^{142}$ BOA, MD, nr. 25, sira: 2879 , s.313

143 BOA, MD, nr.25, sıra: 2879 , s.313. Hisar gediği verilen mimarlarla ilğili kayıt aynen şölcdir. "Hüseyin Abdullah, Mehmed Abdullah, Yusuf Abdullah, Hasan Abdullah, Hamza Abdullah. Ismail Abdullah mezkurlara birer hisar geduği buyruldu tâbi'-i Mimar Ăga"

${ }_{144}$ BOA, MD, nr. 25, sira:817, s.74.

${ }_{14.5}$ BOA, MD, nr. 25, sıra:1246, s. 112; Martal, a.g.m. s.1612

146 BOA. A.RSK, nr.1461, s167

${ }^{147}$ BOA, A.RSK, nr.1461, s167.

${ }^{148}$ BOA, A.RSK, nr.1461, sl67.
} 
belirtilmeyen câmi büyük bir ihtimalle Üskudar'daki Atîk Valide Câmii'dir. Çünkü, İstanbul Üsküdar Toptaşı'ndaki Atîk Valide Câmii'nin yapımına 1570-71 yılında başlanılmış 1583 yılında tamamlanmışıır. ${ }^{149}$ Dolayısıyla Yâni'nin yedi akçelik bir ulûfe ile Hassa mimarlığına atandığı, Behram, Karec ve Namiyeş adlı mimarların ulûfelerinin de birer akçe artırıldığı 6 Ramazan 985/17 Aralık 1577 tarihinde Üsküdar'da inşası devam eden câmi Atîk Valide Câmii'dir.

Mimar Behram, Karec ve Namiyeş Üsküdar Eski Valide Câmii'nin inşası

sırasında Hassa mimarı olduğu halde, Yani Hassa mimarlığına yukarıda belirtilen tarihte atanmıştır. Ulûfelerine birer akçe zam verilmeden önce Behram 6, Karec 13 ve Namiyeş 10 akçe ulûfe almaktaydı. ${ }^{\text {(5) }}$

13 Şevval 992/18 Ekim 1584 tarihli bir kayıtta, hassa mimarbaşısı kaimmakamı Mehmed in arzıyla hassa mimarlarından hizmette bulunan yedi akçeli Yani'nin gediğinin Yorgi adlı bir başka mimara verildiği belirtilmektedir. ${ }^{151}$ Kayıtta Yani'nin kadrosunun hangi nedenle Yorgi ye verildiği açıkça belirtilmemektedir. Ancak büyük bir ihtimalle Yani'nin vefatı veya görev değişikliği sebebiyle yerine Yorgi atanmıştır.

\section{2-KAREC}

6 Ramazan 985/17 Aralık 1577 tarihli bir kayda göre Mimar Karec, Mimar Yani, Behram ve Namiyeş ile birlikte Üsküdar'da olduğu zikredilip de ismi belirtilmeyen fakat büyük bir ihtimalle Atîk Valide Câmii olduğunu tahmin ettiğimiz câminin inşâsında çalışmıştır. ${ }^{152}$ Aynı kayda göre Karec'in maaşı 13 akçeden 14 akçeye çıkarılmıştır.

\section{3-NAMIYES}

Bir kayıttaki bilgilerden Mimar Namiyeş’in de Üsküdar'daki Atîk Valide Câmii olduğunu tahmin ettiğimiz câminin inşasında hizmette bulunduğu anlaşılmaktadır. ${ }^{153} 6$ Ramazan 985/17 Aralık 1577 tarihli kayda göre Namiyeş 10 akçe ulûfe alırken bu câmideki görevinden dolayı ulûfesine bir akçe zam yapılmıştır.

\section{4-BEHRAM}

Mimar Behram da yukarıda belirtiğimiz Mimar Yani, Karec ve Namiyeş ile beraber Üsküdar'daki Atîk Valide Câmii olduğunu tahmin ettiğimiz câminin inşasında çalışmıştır. ${ }^{154} 6$ Ramazan 985/17 Aralık 1577 tarihli aynı kayda göre Behram'ın 6 akçelik ulûfesi yedi akçeye çıkarılmıştır.

\footnotetext{
${ }^{199}$ Bkz.Kuran, a. g. c, s.184-190; Oktay Aslanapa, Osmanlı Devri Mimarîsi, Inkılâp Kitapevi, Istanbul 1986. s.290-293;

${ }^{150}$ BOA, A.RSK, nr.1461, s167.

151 BOA, A.RKS, nr. 244, s.120.

152 BOA, A.RSK, nr.1461, s167.

${ }^{153}$ BOA, A.RSK, nr. 1461 , s167.

${ }^{154}$ BOA. A.RSK, nr.1461, s167.
} 


\section{5-CAFER}

Mimar Cafer, Hersekzade Ahmed Paşa'nın Dil Geçidi'ndeki su yolu bendini inşa eden mimarın, bendin yapımı için verilen altmış bin akçeyi tamamen harcamadığı iddiaları üzerine, Hassa Mimarbaşısı Sinan tarafından bendi tekrar keşfetmekle görevlendirilmiştir. Ayrıca Yalakâbâdd ${ }^{155}$ kadısına da 27 Receb 986/29 Eylül 1578 tarihli bir hüküm gönderilerek bu keşfin yapılmasına yardımcı olması istenilmiştir. ${ }^{156}$

\section{6-HÜSEYIN ÇAVUŞ}

Hüseyin Çavuş, hem Hassa mimarlarından hem de Dergâh-1 Mualla çavuşlarındandır. ${ }^{157}$ Akhisar kasabasında yapılan araştırmalarda Türklerden önceki döneme ait olduğu belirtilen bir kâriz(yer altı su yolu) bulunur. İ̧i ayıklanarak gidildiğinde kârizin başı, Gördük köyü yakınlarında ortaya çıkar. Bazı hayır sahibi Akhisarlılar bu suyu şehre getirmek isterler. Ancak, suyun Gördük tarafında çeltik tarlası olanlar ve değirmen sahiplerinin buna karşı çıkması nedeniyle aralarında kavga çıkar. Bunun üzerine mesele, Divân-ı Hümâyûn'a intikal ettirilir. Divân-1 Hümâyûn Hasssa mimarlarından ve aynı zamanda Dergâh-1 Mualla Çavuşlarından olan Hüseyin Çavuş'u, suyun keşfini yaparak ne durumda olduğunu tespit etmesi için görevlendirir. Mimar Hüseyin Çavuş, bir keşif heyeti oluşturarak suyun keşfini yapar. Keşif neticesinde, suyun şehre getirilmesinin hiç bir kimseye zarar vermeyeceğinin belirtilmesi üzerine Divân-1 Hümâyûn, Akhisar kadısına 15 Receb 989/15 Ağustos 1581 tarihli bir hüküm göndererek, kendi paralarıyla suyu Akhisar’a getirmek isteyenlerin, kendi mülk ve hamamlarına akıtmamak ve Allah rızası için çeşmeler inşâ etmek şartıyla, suyu getirmelerinde bir sakıncanın olmadığını ve bundan sonra bu işe hiç bir kimsenin müdahale etmemesi gerektiğini bildirir. ${ }^{158}$

Mimar Hüseyin Çavuş 16 Safer 992/28 Şubat 1584 tarihli bir başka hükümle, yıldırım düşmesi sonucu bir minaresi ve bazı yerleri zarar gören Edirne Selimiye Camii'nin tamirinde de görevlendirilmiştir. ${ }^{159}$ Bu tamirin keşfi, Divân-ı Hümâyûn'ın 10 Muharrem $992 / 23$ Ocak 1584 tarihli bir hükmü üzerine bizzat Mimar Sinan tarafından yapılmıştır. ${ }^{160}$ Mimar Hüseyin Çavuş un ismi, bu tamirle ilgili olarak görevlendirilen kişilerin adlarının verildiğı başka bir kayıtta "Nâzır-ı binâ Hüseyin Mimar" şeklinde geçmektedir. ${ }^{161}$ Böylece bu kayıttan, Mimar Hüseyin Çavuş'un Edirne Selimiye Câmii'nin 1584 yılında geçirmiş olduğu tamirde bina nazırı olarak görev yaptığı anlaşılmaktadır. Başka bir kayda göre ise Mimar Hüseyin, Hassa

155 Yalakâbâd, Yalakova adıyla da anılan bugünkü Yalova ilidir(Bkz. Enver Ziya Karal, Osmanll Tarihi, VI. Cilt. 3. Baskı, Türk Tarih Kurumu Basımevi, Ankara 1983, s.251; Türk Ansiklopedisi, Cilt:33, s.390-391). Mimar Cafer'in Dil Geçidi'ndeki su bendinde yapacağı keşfe Yalakâbâd kadısından yardımcı olması istendiğine göre, Dil Geçidi'nin de muhtemelen bugünkui Yalova ili'nin sınırları içerisinde olması gerekir.

154 BOA, MD, nr. 35. sira:737, s.291.

157 BOA, MD, nr. 42, sıra: 374 , s.96. Bu durum, Divân-1 Hümâyûn tarafından 16 yüzyılda çeşitli yapıların inşaları ve tamirleriyle görevlendirilen Dergâh-ı Mualla çavuşlarından pek çoğunun mimar veya mimarlık işlerinde mahareti olan kişiler olduklarını göstermektedir.

${ }^{158}$ BOA, MD, nr. 42, sira: 374, s. 96.

159 BOA, MD, nr. 52, sira: 707, s.267.

16(1) BOA, MD, nr. 52, sira: 586, s.224.

161 BOA, KK, nr. 242, s.171. 
mimarlarından on iki akçe ulûfeli Mustafa ile sekiz akçeli Mahmud'un vefat etmeleri üzerine, boşalan yirmi akçelik kadrolarının beş akçelik bölümüne sefere gitmek şartıyla 26 Rebiyülevvel 994 / 17 Mart 1586 tarihinde Hassa mimarlığına atanmıştır. ${ }^{162}$

Mimar Hüseyin Çavuş un ismine, Muharrem 999/ Eylül 1590 tarihli başka bir kayıtta Edirne Selimiye Camii etrafındaki kaldırım döşemelerinde görev alan mimarlar arasında da rastlanılmaktadır. ${ }^{163}$ Aşağıda zikredeceğimiz Ahmet Halife günlük ücretle çalıştı̆̆ı halde ilgili defterdeki kayıtta, Hüseyin Çavuş’un günlük ücretle çalıştığına dair herhangi bir bilgi yoktur. Ancak defterdeki diğer bilgilerden bazı ödemelerin Hüseyin Çavuş’ın bilgisi dahilinde yapıldığı anlaşılmaktadır. Dolayısıyla bu durum onun kaldırım döşemelerinde de bina nazını olarak görev almış olabileceğini akla getirmektedir.

\section{7-MEHMED SUBAŞI}

Hassa mimarlarından olan Mehmet Subaşı, Mimar Sinan'ın hacca gitmesi üzerine, Divân-ı Hümâyûn'un 16 Safer $992 / 26$ Şubat 1584 tarihli bir kararıyla vekaleten mimarbaşılığa atanmıştır. ${ }^{164}$ Vezir Mesih Paşa ${ }^{165}$ Divân-ı Hümâyûn'a müracaat ederek, Ali Paşa Hamamı yakınlarındaki Hasan Paşa Mescidi’ni ${ }^{166}$ câmi yapmak istediğini belirtip gerekli iznin verilmesini ister ${ }^{167}$ Bunun üzerine Divân-1 Hümâyûn, mimarbaşı kaimmakamı Mehmet Subaşı'ya 2 Rebiyülevvel 992 / 14 Mart 1584 tarihli bir hüküm göndererek, Mesih Paşa'ya istenilen iznin verildiğini belirtip kendisinin de câminin inşâsında çălı̧acak usta ve ırgadlar ile gerekli malzemenin temin edilmesine yardımcı olması istenmiştir. ${ }^{16 / 3}$

\footnotetext{
${ }^{162}$ BOA. A. RSK. 246, s. 188

${ }_{163}$ TSMA, D. $1684 / 5$, s.5A ve $6 \mathrm{~B}$

$164 \mathrm{BOA}, \mathrm{MD}, \mathrm{nr} .52$, sira: 714 , s. 269

${ }^{\circ}$ Kayıtta, Hasan Paşa Mescidi'ni câmi yapmak isteyen kişinin adı yukarıda da belirtildiği gibi sadece "Vezir Mesih Paşa" olarak geçmckte olup ismi açıkça zikredilmemcktedir. Ayvansarâyî ve Mehmed Süreyya da aynı kişiden bahsettikleri halde farklı isimler vermektedirler. Ayvansarâyî "Vezir Mesih Paşa"nın Mehmed Paşa olduğunu belirtirken, Mehmed Süreyya bunun Süleyman Paşa olduğunu söylemektedir. Her iki yazar da bahsettikleri bu kişinin mezarının, yine kendisinin inşa ettirdiğini söyledikleri Mesih Ali Paşa Câmii adıyla da anılan Mesih Paşa Câmii'nin avlusunda bulunduğunu belirtmektedirler(Hafız. Hüseyin Ayvansarayî, Hadikatü'l-Cevâmi, Cilt. III, Matbaa-i Amire, Sene 1281, s. 192; Mchmed Surcyya, Sicill-i Osmânî, (Haz: Nuri Akbayar), Cilt:4, Tarih Vakfı Yurt Yayınlan. İstanbul 1996, s.1087)

160 Ayvansarâyî'nin bahscttiğinc göre, Vezir Mesih Mehmed Paşa, Hasan Paşa Mescidi'nin yerine bir câmi yaptırmak istediğinde bu mescidi Karagümrük'te uygun bir yere naklettirmiştir. Bu bilgilere göre, Hâdim Mesih Mehmed Paşa tarafından yaptırılan ve Karagümrük Mescidi, Sütçü Murad Mescidi, Mesih Paşa Mescidi ve Fetva Emîni Câmii adlarıyla anılan eser, İstanbul Fatih'te Edirnekapı civarında Hatice Sultan Mahallesi Lökümcüler Caddesi'ndedir. Kaynaklara göre yapımı 1588 yılında tamamlanmıştır. Zamanla harap olduğundan II. Abdülhamid dönemi Fetva Eminlerinden $\mathrm{Hac}_{1}$ Nuri Efendi tarafından yenilenmiştir. Câmiin duvarları kârgir kubbesi demir iskeletli olup tek şerefeli ve tuğladan bir de minaresi vardir (Bkz. Komisyon, Fâtih Câmileri, Türkiye Diyanet Vakfı Fâtih Subesi Yayınları, İstanbul 1987, s.163-164; Hafı Hüseyin Ayvansarayî, Hadikatü'l-Cevâmi, Cilt. I-II, Matbaa-i Amire, Sene 1281 s. 174; 'Tahsin Öz, Istanbul Camileri, I. Cilt, Türk Tarih Kurumu Basımevi, Ankara 1987, s.83).

${ }^{167} \mathrm{BAO}, \mathrm{MD}$, nr. 52, sira:854, s.322.

to6 BAO, MD, nr. 52, sira:854, s.322.
} 
Dik bir yamaç üzerine kurulan ve alt katında sekiz dükkânı, bir çeşmesi küçük bir de haziresi bulunan Mesih Paşa Câmii, İstanbul Fatih te Muhtesip İskender Mahallesi Hırka-i Şerif Câmii yakınlarında eski Ali Paşa Caddesi üzerindedir. Halk arasında Mesih Ali Paşa Câmii olarak da bilinen eserin inşası 1586 yılında tamamlanmıştır. ${ }^{169}$ Sekiz destekli câmiler grubuna giren eserin orta kubbesi, köşelere birer eksedra ile bağlanırken yanlara doğru mahfiller üzerinde uiçer küçük kubbe ile de genişletilmiştir. Dışa taşan mihrap kısmı yarım kubbecikle örtülmüştür. Beş gözlü son cemaat yerinin orta kısmı çapraz tonozlu diğer bölümler ise kubbelidir. Üç tarafı kubbeli dar revaklarla çevrili avlunun ortasında şadırvan yerine Mesih Paşa'nın sekizgen açık türbesi bulunmaktadır. Avlu revaklarının doğu-batı bölümlerine ise birer hücre yerleştirilmiştir. Minare câmiin kuzey doğu köşesindedir. Mermer mihrabın etrafındaki ve pencere alınlıklarındaki çini süslemeler ile geometrik şebekelerle işlenmiş minber eserin önemli unsurlarındandır. Kısaca tanıtmaya çalıştığımız ve Mimar Sinan'a atfedilen yapıların isimlerinin verildiği tezkerelerde de adina rastlanmayan ${ }^{170}$ Mesih Paşa Câmii Mimar Davud Ağa'ya maledilmektedir. ${ }^{171}$ Ancak yukarıda verdiğimiz bilgilerden, Mesih Paşa Câmii'nin inşaat izninin, Mimar Sinan’ın hacca gittiği dönemde ve Mehmed Subaşı'nın vekâleten mimarbaşılık görevini yürüttüğü bir tarih olan 14 Mart 1584 verilmesinin anlaşılması, bir taraftan bu eserin tezkelerde adının geçmeme gerekçesini açıkça ortaya koyarken, diğer taraftan da Mimar Davud Ağa ile bir bağlantısının olmadığını göstermektedir. Böylece bu bilgilerden Mesih Paşa Câmii mimarının Mehmed Subaşı olduğu anlaşılmaktadır.

\section{8-YORGİ BÎKÂR(?)}

Yorgi Bîkâr, 13 Şevval 992/18 Ekim 1584 tarihinde yedi akçe ulûfe ile hassa mimarlarından olan Yani nin yerine atanmıştır. ${ }^{172}$

\section{9-TODOR YANI}

Todor Yani hassa mimarlarından olup yedi akçe ulûfe almaktaydı. Ancak 13 Şevval 992/18 Ekim 1584 tarihinde yerine Dimitri Veledi Yorgi atanmıştır. ${ }^{173}$

\section{0-DİMITRİ VELEDI YORGI}

13 Şevval 992/18 Ekim 1584 tarihli bir kayda göre yedi akçe ulûfe alan Todor Yani’nin yerine Dimitri Veledi Yorgi atanmıştır. ${ }^{174}$

\section{1-AHMED REİS}

Ahmed Reis, Mimar Mehmed ile birlikte Saray-ı Âmire'de inşa edilen Bîmarhane'nin mimarlığını yapmıştır. Bu hizmetinden dolayı Ahmet Reis'in ücretine 24 Ramazan 992/29 Eyluil 1584 tarihinde üç akçe zam yapılmıştır. ${ }^{175}$

\footnotetext{
${ }^{16 *}$ Bkz. Fâtih Câmileri, s.162-163; Ayvansarayî, a.g.e, s.192-193; Öz, a.g.e. s.104.

${ }^{170} \mathrm{Bkz}$. Kuran, a. g. e, s.249-405.

${ }^{171}$ Aslanapa, a.g. e. s.306-307

172 BOA, KK, A.RSK, nr. 244. s.120.

${ }_{173}$ BOA, KK. A.RSK, nr. 244. s.120.

${ }^{174}$ BOA, KK, A.RSK, nr. 244, s.120.
} 


\section{2-ÜSTAD MUSTAFA}

Üstad Mustafa, Mimar Musluhiddin in $992 / 1584$ yılında vefatı üzerine 13 akçe ulûfesinin sekiz akçesiyle Mimarbaşı Kaim-i Makamı Mehmed Subaşı'nın arzıyla Hassa mimarlığına atanmıştır. ${ }^{176}$ Mustafa'nın Hassa mimarlığına geçirilmesinin gerekçesi üstad mimarlardan olmasıdır.

26 Rebiyülevvel 994/17 Mart 1586 tarihli bir kayıttan Mimar Mustafa'nın ulûfesinin 12 akçe olduğu ve vefat ettiği anlaşılmaktadır. ${ }^{17}$ Kayıtlardaki bu bilgilere göre Mimar Mustafa'nın Hassa mimarlığı yaklaşık iki yıl sürmüş̧ür.

\section{3-ÜSTAD MAHMUD}

Üstad Mahmud, Mimar Musluhiddin'in 992/1584 yılında vefatı üzerine 13 akçe ulûfesinin 5 akçesini Kaçak Derbendi'nde bennâ olan ancak ismi belirtilmeyen bir kalfa ile paylaşarak 2.5 akçe karşılığında Hassa mimarlığına atanmıştır. ${ }^{178}$ Üstad Mahmud, Hassa mimarı olduğu 18 Rebiyülevvel 992/30 Mart 1584 tarihinde Üsküp'de inşası devam eden ancak kayıtta ismi belirtilmeyen bir köprünün mimarlığını yapmaktaydı. ${ }^{179} 26$ Rebiyülevvel 994/17 Mart 1586 tarihli başka bir kayıttan, Mimar Mahmud'un ulûfesinin sekiz akçe olduğu ve bu tarihte vefat ettiği anlaşılmaktadır. ${ }^{\text {ISO }}$

\section{4-ISMAILL NECCAR}

Üstad mimar olduğu belirtilen İsmail Neccar Cemaat-1 Cebeciyân-1 Hassa'dandır. Mimara şiddetle ihtiyą̧ duyulduğundan sefere gitmek şartıyla Hassa mimarlarından boşalan gediğe 8 akçe ulûfe ile 992/1584 yılında Hassa mimarları zümresine ilhak edilmiştir. ${ }^{181}$

\section{5-HACI MEHMED}

Mimar Ahmed'in ölümüyle boşalan onüç akçelik kadrosunun günlük dört akçesi 13 Şevval 994/27 Eylül 1586 tarihinde Úsküdar'da ikâmet ettiğ anlaşılan Mimar Hacı Mehmed'e verilmiştir. ${ }^{182}$

\section{6-SERGICI OĞLU MİKOLA}

Mimar Ahmed'in vefatıyla boşalan onüç akçelik kadrosunun yevmî dört akçesi Rebiyülahir 994/Mart 1586 tarihinde Sergici oğlu Mikola'ya verilmiştir. ${ }^{183}$ Araştırmalarımızda Sergici oğlu Mikola'nın faaliyetleriyle ilgili herhangi bir bilgiye rastlayamadık.

\footnotetext{
${ }^{175}$ BOA. KK. A. RSK.nr. 244. s. 103

${ }^{176} \mathrm{BOA}, \mathrm{KK}, \mathrm{nr} .242$. s. 247

in BOA, KK, A.RSK, nr. 246, s.188.

${ }^{178} \mathrm{BOA}, \mathrm{KK}, \mathrm{nr} .242$. s.246.

${ }^{179} \mathrm{BOA}, \mathrm{KK}, \mathrm{nr} .242$, s. 246.

${ }^{180}$ BOA, KK, A.RSK, nr. 246, s.188.

${ }^{181}$ BOA. KK, nr. 242, s.247.

${ }^{182} \mathrm{BOA}, \mathrm{KK}$. A. RSK, nr.248, s.6.

${ }^{183}$ BOA, KK. A. RSK, nr. 248, s.6.
} 


\section{7-MEHMED}

Hassa mimarlarında olup günlük yedi akçe ulûfe almaktaydı. Ancak Mimar Ahmed'in vefat etmesi üzerine boşalan on üç akçelik kadrosundan iki akçesi 13 Şevval 994/27 Eylül 1586 tarihinde Mehmed'e verilmiştir. ${ }^{184}$ Böylece Mehmed'in ulûfesi yevmî dokuz akçeye çıkmıştır.

\section{8-MEHMED}

Hassa mimarlarından olup yevmî on akçe ulûfe almaktaydı. Mimar Ahmed'in ölümüyle boşalan on üç akçelik gediğinin iki akçesi 13 Şevval 994/27 Eylül 1586 tarihinde Mehmed'e verilmiştir. ${ }^{185}$ Böylece Mehmed'in ulûfesi yevmî on iki akçeye yükselmiştir.

\section{9-MEHMED}

Mimar Mehmed, Hassa mimarlarından oniki akçe ulûfesi olan Mustafa'nın ve sekiz akçesi bulunan Mahmud'un ölmeleri nedeniyle boşalan yirmi akçelik kadrosunun beş akçesine sefere gitmek şartıyla 26 Rebiyülevvel 994/17 Mart 1586 tarihinde Hassa mimarlığına atanmıştır. ${ }^{186}$ Mimar Ahmed'in vefatıyla da boşalan on üç akçelik gediğinin bir akçesi 13 Şevval 994/27 Eylül 1586 tarihinde Mimar Mehmed'e verilerek ulûfesi günlük altı akçeye çıkarılmıştır. ${ }^{187}$

\section{0-YANİ}

Mimar Yani, Hassa mimarlarından oniki akçe ulûfeli Mustafa ile sekiz akçeli Mahmud'un vefat etmeleri üzerine, boşalan yirmi akçelik ulûfelerinin beş akçelik bölümüne sefere gitmek şartıyla 26 Rebiyülevvel 994 / 17 Mart 1586 tarihinde Hassa mimarlığına atanmıştır. ${ }^{188}$

\section{1-BALI}

Hassa mimarlarından olup yevmî beş akçe ulûfe almaktaydı. 994/1585-1586 yılında ismi belirtilmeyen ancak tarihi kaynaklardan Ferhad Paşa'nın ikinci defa Şark Serdarlığı'na tayin edilmesiyle yapılan şark sefer-i hümayûn-1 ${ }^{189}$ için görevlendirilmişti. Ancak bu göreve gitmediğinden Mimarbaşı Sinan’ın isteği üzerine, 13 Şevval 994/27 Eylül 1586 tarihinde bu beş akçelik gediği kendisinden alınarak Haci Bulgar'a verilmiştir. ${ }^{190}$

\section{2-íSMAIL BIN ABDULLAH}

Bir kayıtta "Cemaat-ı Mi'mârân-ı Hassa"dan olduğu belirtilen İsmail bin Abdullah, Süleyman Abdullah, Dede Halife, Bulgar Hacı ve Mustafa bin Abdullah

\footnotetext{
${ }^{184}$ BOA, KK. A. RSK, nr. 248, s.6.

${ }^{185}$ BOA. KK. A. RSK, nr. 248, s. 6

${ }^{186} \mathrm{BOA}, \mathrm{A}$. RSK. nr. 246, s. 188.

${ }^{187}$ BOA, KK. A. RSK, nr. 248, s.6.

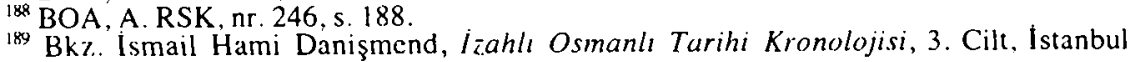
1950, s.100-117.

(4) $\mathrm{BOA}$, KK. A. RSK, nr. 248, s.6.
} 
ile beraber Gori Kalesi'ni ${ }^{191}$ inşâ etmiştir. ${ }^{192}$ Bu mimarlar içerisinde sekiz akçeyle en yüksek yevmiyeyi İsmail bin Abdullah almıştır. Dolayısıyla bu durum, Mimar İsmail bin Abdullah'ın diğer dört mimara göre daha deneyimli ve bu kalenin inşasında onların başkanları olduğunu göstermektedir. Ayrıca Gori Kalesi’nin yapımında gösterdikleri üstün başarı nedeniyle Şevval 995/Eylül 1587 tarihinde diğer mimarlara birer akçe zam verildiği halde İsmail bin Abdullah'a iki akçe verilmiştir. Böylece İsmail bin Abdullah'ın maaşı on akçeye yükselmiştir. ${ }^{193}$

\section{3-SÜLEYMAN ABDULLAH}

Cemaat-1 Mi'mârân-1 Hassa'dan olan Süleyman Abdullah, İsmail bin Abdullah, Dede Halife, Bulgar Hacı ve Mustafa bin Abdulah ile beraber Gori Kalesi'nin inşasına katılmıştır. Bu mimarların sıralanmasında, İsmail bin Abdullah'in arkasından ikinci sırada yer alan Süleyman Abdullah günlük yedi akçe ücret almıştır. Bu kalenin yapımından sonra Şevval 995/Eylül 1587 tarihinde kendisine bir akçe zam yapılarak yevmiyesi sekiz akçeye çıkmıştır. ${ }^{194}$

\section{4-DEDE HALIIFE}

Kayıtlarda Dede Halife veya Dede olarak geçen Mimar Dede, onüç akçe ulûfe alan Mimar Mustafa ve oniki akçe ulûfeli Mimar Mahmud'un vefat etmesi üzerine bu iki mimardan boşalan yirmi akçelik ulûfenin beş akçesine sefere gitmek şartıyla 26 Rebiyülevvel 994/17 Mart 1586 tarihinde Hassa mimarlığına atanmıştır. ${ }^{195}$ Böylece Cemaat-1 Mi'mârân-1 Hassa'dan olan Dede Halife, İsmail bin Abdullah, Süleyman Abdullah, Bulgar Hacı ve Mustafa bin Abdullah ile beraber Gori Kalesi'nin yapımında çalışmışıı. Süleyman Abdullah'ın arkasından üçüncü sırada yer alan Dede Halife günlük beş akçe ücret almıştır. Kalenin inşasından sonra kendisine Şevval 995/Eylül 1587 tarihinde bir akçe zam yapılarak yevmiyesi altı akçeye yükseltilmiştir. ${ }^{1 x_{\text {i }}}$

\section{5-HACI BULGAR}

Kayıtlarda Bulgar Hacı veya Hacı Bulgar olarak geçmektedir. ${ }^{197}$ "Dirliksiz mimarlardan" olduğu zikredilen Hacı Bulgar, 994/1585-1586 yılında ismi belirtilmeyen sefer-i hümayûn ile görevlendirilen Bâli'nin bu göreve gitmemesi nedeniyle, Mimar Sinan'ın isteği üzerine 13 Şevval 994/27 Eylül 1586 tarihinde, günlük beş akçe ulûfe ile Bâli'nin yerine atanmıştır. ${ }^{198}$ Bundan sonra Cemaat-1 Mi'mârân-1 Hassa içinde yer alan Hacı Bulgar, İsmail bin Abdullah, Süleyman

191 Gori Gürcistan'ın Kura Irmağı kıyısında yer alır ve Gürcistan'ın en eski şehirlerinden biridir(Bkz. AnaBritannica, Cilt: 9, İstanbul 1988, s.550). Tarihi kaynaklarda 27 gün gibi kısa bir sürede inşâ edildiği belirtilen Gori Kalesi şöyle tavsif edilmektedir: "Bir a'lâ kapu, nice yüz zira' divâr, kuleler ve hisariçesi ve kar-nâk hendekli" (Bkz. Danismend, a.g.e, s. 106).

192 BOA, KK, A.RSK, nr. 248, s. 54.

193 BOA, KK, A.RSK, nr. 248, s.54.

194 BOA, KK, A.RSK. 248, s.54.

195 BOA, KK, A. RSK. 246, s.188.

196 BOA, KK, A.RSK. 248, s.54.

${ }^{197}$ BOA, KK. A. RSK. 248, s.6, s.54.

${ }^{198}$ BOA, KK. A. RSK. 248, s.6. 
Abdullah, Dede Halife ve Mustafa bin Abdullah ile beraber Gori Kalesi'ni inşa etmiştir. Dede Halife yle birlikte aynı ücreti aldığı halde sıralamada ondan sonra zikredilmiştir. Bu kalenin inşasından sonra kendisine Şevval 995/Eylül 1587 tarihinde bir akçe verilerek ücreti altı akçeye çıkarılmıştır. ${ }^{\mid(\%)}$

\section{6-MUSTAFA BIN ABDULLAH}

Cemaat-1 Mi mârân-1 Hassa'dan olan Mustafa bin Abdullah, İsmail bin Abdullah, Süleyman Abdullah, Dede Halife ve Hacı Bulgar ile birlikte Gori Kalesi’nin yapımında çalışmışır. Dede Halife ve Hacı Bulgar ile aynı ücreti alan Mustafa bin Abdullah'ın yevmiyesi bu kalenin yapımından sonra Sevval 995/Eyluil 1587 tarihinde bir akçe artırılarak altı akçeye yükseltilmiştir. ${ }^{200}$

\section{7-AHMED}

Hassa mimarlarından olup on üç akçe ulûfe almaktaydı. Kayıtta hangi sefer olduğu ve isimleri belirtilmeyen on mimar ile birlikte sefer-i hümayûnla görevlendirilmişti. Ancak Rebiyülahir 994 / Mart 1586 tarihinde vefat ettiğinden bu sefere katılamadığı anlaşılmaktadır. ${ }^{201}$

\section{8-AHMED HALIFE}

Muharrem 999/ Eylül 1590 tarihli bir kayıttan, Mimar Ahmed Halife nin Edirne Selimiye Cami nin etrafında yapılan kaldırım düzenlemelerinde yevmiyesi dokuz akçeden 22 gün çalıştığı ve toplam 198 akçe uicret aldığı anlaşılmaktadır ${ }^{202}$

\section{9-MEHMED BIN AHMED}

Bir kayda göre, yedi akçe ulûfeyle top arabacılarından olduğu belirtilen Mehmed bin Ahmed, mimarbaşının "üstad ve sengtıraş ve ilm-i binada mâhirdir" ifadesiyle Hassa mimarlığına geçirilmesi isteği uygun görülerek, 1001/1592 yılında yedi akçe ulûfe ile Hassa mimarlığ̣̆na atanmıştır. ${ }^{20.3}$.

\section{0-MIMAR ACEM}

Mimar Acem'in ismine 16. yüzyılda Saray-1 Cedid'deki eski ve yeni ફ̧adırvanlar ve çeşmelere gelen suların taksiminde yapılan düzenlemelerle ilgili defterde rastlanılmaktadır ${ }^{204}$ Defterdeki bilgilere göre on lüle sudan altı lülesinin mimar Acem in çalışmasının ürünü olduğu anlaşılmaktadır. ${ }^{205}$

\footnotetext{
199 BOA, KK, A.RSK. 248, s.54.

BOA, KK, A.RSK. 248, s.54.

2)1 BOA, KK. A. RSK. 248. s.6.

202 TSMA, D. $1684 / 5$, s.2B.

${ }^{20.3}$ Mehmed bin Ahmed ile ilgili kayıt aynen söyledir: "Mimarbaşı mektub gönderub tob arabacilartndan yedi akcesi olan Melimed bin Ahmed ifun üstad ve senguras ve ilm-i binada mâhirdir deyu uluffesiyle Hassa mimarlığma ilhak olmak ricasma arz etmeğin mahlul var ise verilmek buyurulub badehu uliffesiyle verilmek buyruldu sene l00l/l592" (BOA, KK. A.RSK, nr. 253, s. 75).

2in Geniş bilgi jçin bkz.TSMA. D. 10137.

215 TSMA, D. 10137.
} 


\section{1-MIMAR HAMZA}

Mimar Hamza'nın ismine de, 16. yüzyılda Saray-1 Cedid'deki eski ve yeni şadırvanlar ve çeşmelere gelen sulaıın taksiminde yapılan düzenlemelerle ilgili defterde tesadüf edilmektedir. ${ }^{206}$ Buradaki bilgilere göre dört lüle suyun Mimar Hamza'nın çalışmalarının neticesi olduğu anlaşılmaktadır. ${ }^{207}$

\section{2-MUSA USTA}

Mimar Sinan’ın kalfalarından olduğu anlaşılan Musa Usta, Hindistan yöneticilerinin Osmanlı devletinden mimar istemeleri üzerine, Kanuni Sultan Süleyman tarafından Hindistan'a gönderilmiştir. ${ }^{208}$ Musa Usta'nın Hindistanda'ki faaliyetleri arasında, Hindistan limanlarında Anadolu üslûbunda büyük binalar inşa ettirdiği ayrıca bazı onarımlarda bulunduğu zikredilmektedir ${ }^{209}$ Kaynaklarda Musa Usta'nın Hindistan'daki bu faaliyetleri dışında herhangi bir bilgiye rastlanilmamaktadır.

\section{3-CAFER OĞLU MUSTAFA BİN AHMED}

Hassa mimarlarından olup günlük onsekiz akçe ulûfe almaktaydı. Hicrî 1001 Milâdî 1592-1593 yıllarına ait bazı kayıtları ihtiva eden bir defterdeki bir kayda göre Cafer oğlu Mustafa bin Ahmed'den boşalan hassa mimarlığı kadrosuna, Mimarbaşı Davud Ağa'nın ${ }^{210}$ isteğiyle Sinan oğlu Derviş beş akçe ulûfe ile atanmıştır."11 Aynı kayılttaki bilgilerc göre, Cafer oğlu Mustafa bin Ahmed din geriye kalan ulûfesi ise, hassa mimarlarından oldukları belirtilen Veli bin Mahmud'ın, Yusuf oğlu Mehmed'in, Hacı Sefer'in, İsmail Halife'nin, Sinan bin Abdullah'ın, İlyas Abdullah'ın, Yani Nakkaşoğlu'nun, Anton Kalfa'nın, Yani Eskisarana'nın, Yani Kalfa'nın ve Yorgi Minareci'nin ulûfesine birer akçe zam yapılarak dağıtılmıştır. ${ }^{212}$

\section{4-SINAN OĞLU DERVIŞ}

Hicrî 1001 Milâdî 1592-1593 yıllarına ait çeşitli konulardaki bazı kayıtlanı içeren bir defterdeki bir kayda göre Sinan oğlu Derviş, Cafer oğlu Mustafa bin Ahmed'den boşalan onsekiz akçelik kadronun beş akçesine Hassa mimarı olarak atanmıştır. ${ }^{213}$

\footnotetext{
$2 m$ TSMA, D. 10137

${ }^{210}$ TSMA, D 10137 .

${ }^{2 a r}$ Mustafa Nuri Pạ̧a, Netavic ül-Vukuat Kurumları ve Örgütleriyle Osmantl Tarihi, Cilt: I-II, (Sadeleştiren: Neşet Çağatay). Türk Tarih Kurumu Basımevi. Ankara 1987, s. 163 164.

20(1) Mustafa Nuri Paşa, a.g.e. s.164.

211) Davud A ğa hakkinda bk7. Ahmet Refik Altınay, Türk Mimarları. (Hazırlayan: Zeki Sönmez). Sander Yayınları Ístanbul 1977. s.61-72; Mu7affer Erdoğan, "Mimar Davud Ağa'nın Hayatı ve Eserleri". Türkivat Mecmuası, Cilt: 12, Osman Yalçın Matbaası, İstanbul 1955, s.179-204.

$211 \mathrm{BOA}, \mathrm{KK}, \mathrm{nr} .253$. s. 216.

${ }^{212}$ BOA, KK, nr. 253, s. 216.

${ }_{213} \mathrm{BOA}, \mathrm{KK}, \mathrm{nr} .253$. s. 216.
} 


\section{5-VELİ BÍN MAHMUD}

Hassa mimarlarından olan ancak kaç akçe ulûfe aldığı kayıtlarda belirtilmeyen Veli bin Mahmud'un ulûfesine Hicrî 1001/1592-1593 senesinde bir akçe zam yapılmıştır. ${ }^{214}$

\section{6-YUSUF BIN ABDULLAH}

Hicrî 1001/1592-1593 senesine ait bir kayıttaki bilgilerden Hassa mimarlarından olduğu anlaşılan Yusuf bin Abdullah'ın ulûfesi bir akçe arttırılmıştır. $^{215}$

\section{7-MEHMED KASIM PAŞA}

Hassa mimarlarından olan Mehmed Kasım Paşa'nın ulûfesine Hicrî 1001/1592-1593 senesinde bir akçe zam yapılmıştır. ${ }^{216}$

\section{8-YUSUF OĞLU MEHMED}

Hassa mimarlarından olan Yusufoğlu Mehmed'in ulûfesinin Hicrî 1001/15921593 yılına ait bir kayıttan bir akçe artırıldığı anlaşılmaktadır. ${ }^{217}$

\section{9-HACI SEFER}

1592-1593 yıllarına ait bir kayıtta ulûfesine bir akçe zam yapıldığı belirtilen Hacı Sefer Hassa mimarlarındandı. ${ }^{218}$

\section{0-ISMAIL HALIFE}

Hassa mimarlarından olan İsmail Halife'nin ulûfesi Hicrî 1001/1592-1593 senesinde bir akçe arttırılmıştır. ${ }^{2 ! 9}$

\section{1-SINAAN BINN ABDULLAH}

Hassa mimarlarından olan Sinan bin Abdullah'ın ulûfesine Hicrî 1001/15921593 senesinde bir akçe zam yapılmıştır. ${ }^{220}$

\section{2-IL YAS ABDULLAH}

Hicn̂ 1001/1592-1593 senesine ait bir kayda göre Hassa mimarlarından olduğu anlaşılan İlyas Abdullah'ın ulûfesine bir akçe zam yapılmıştır. ${ }^{221}$

\section{3-YANİ NAKKAŞOĞLU}

Hassa mimarlarından olan Yani Nakkaşoğlu'nun Ulûfesine Hicrî 1001/15921593 senesine ait bir kayda göre bir akçe zam yapılmıştır. ${ }^{222}$

\footnotetext{
${ }^{214}$ BOA, KK, nr. 253, s. 216

${ }^{215}$ BOA, KK, nr. 253, s. 216

${ }^{216}$ BOA, KK.nr. 253, s. 216

${ }^{217}$ BOA, KK, nr. 253, s. 216

${ }^{218}$ BOA, KK, nr. 253, s. 216

${ }^{219}$ BOA, KK, nr. 253, s. 216.

$220 \mathrm{BOA}, \mathrm{KK}, \mathrm{nr} .253$, s. 216

${ }^{221}$ BOA, KK. nr. 253, s. 216.

222 BOA, KK. nr. 253, s. 216.
} 


\section{4-ANTON KALFA}

Ulûfesi Hicrî 1001/1582-1583 senesine ait bir kayda göre bir akçe arttrrılan Anton Kalfa Hassa mimarlarındandı. ${ }^{223}$

\section{5-YANI ESKISSARANA}

1592-1593 yıllarına ait bir kayda göre Hassa mimarlarından olduğu anlaşılan Yani Eskisarana'nın ulûfesi bir akçe artıırılmıştır. ${ }^{224}$

\section{6-YANİ KALFA}

Hassa mimarlarından olan Yani Kalfa'nın ulûfesine Hicrî 1001/1592-1593 senesinde bir akçe zam yapılmıştır. ${ }^{225}$

\section{7-YORGI MINARECI}

Ulûfesi Hicrî 1001/1592-1593 yılında bir akçe arttırılan Yorgi Minareci Hassa mimarlarındand. ${ }^{226}$

\section{SONUC}

Osmanlı devletinde faaliyet gösteren bütün mimarlar, imparatorluktaki imar, inşa, tamir ve bayındırlık hizmetlerini yürüten merkezdeki Hassa Mimarlar Ocağı ile bir taşra mimarlık teşkilâtı olan Eyalet Mimarlıklarına bağlı değildi. Ancak sahalarında temayüz eden mimarların bu teşkilâtlarda yetiştikleri görülmektedir. Dolayısıyla serbest çalışan mimarlar ancak belirli bir noktaya kadar mesleklerini sürdürebilmişlerdir. Zaten Hassa Mimarlar Teşkilâtı'na bağlı olmayan mimarlar da, bilgi, beceri ve deneyimlerini ya bizzat devletin inşa ettirdiği yapılarda ya da önde gelen devlet adamlarının yaptırdığ ispatlamışlardır. Böylece mimarlık mesleğinde kendini gösteren mimarlar, Osmanlı devletinin hangi bölgesinde olurlarsa olsunlar Hassa Mimarlı̆̆ı'na dahil edilerek, bilgi ve becerilerini daha da geliştirme imkân ve fırsatını elde etmişlerdir. Çünkü Hassa Mimarları için her zaman devamlı iş imkânı vardı.

XVI. yüzyılın büyük bir bölümünde mimarbaşılık görevini yapmış olan Mimar Sinan'a atfedilen yapılarda da Hassa Mimarları'nın çalışıkları görülmektedir. Mescla, Süleymaniye Câmii'nde Mustafa bin Abdullah ve Mustafa bin Nebi mermercilik işlerini yürüten mimar olarak görev alırken, Karapınar Sultan Selim Câmii'nin mimarlı̆̆ını ise Mimar Mehmed yapmışıır.

Hassa Mimarları'nın her türlü inşa ve tamir işleriyle görevlendirilmelerinin yanısıra, belirli bir yapı dalında yetişmiş olanlarına da rastlanmaktadır. Meselâ, Mimar Agusto'nun gemi yapımında, Mimar Kasım, Mimar Todor ve Mimar Kosta'nın kale yapımı ve tamirinde ve Ústad Bâli'nin ise su yollarının inşasında daha deneyimli oldukları anlaşılmaktadır. XVI. yüzyılda, mimarlar açısından 
görülen diğer önemli bir gelişme de, eyalet merkezlerine Hassa Mimarları'ndan birer mimarın atanarak "Mimarbaşı" unvanıyla anılmalarıdır. Örneğin, 1556 yılında Van Eyaleti'ne Selman adlı bir zımmî, Erzurum Eyaleti'ne ise Hoca Can adlı bir mimar Eyalet Mimarı olarak atanmıştır. 1567 yılında ise Üsküb Eyaleti'nin mimarlığını Hayreddin' in yürüttuğŭu anlaşılmaktadır.

XVI. yüzyıl Osmanlı mimarları içerisinde gayri müslim mimarların da bulunduğu görülmektedir. Bu yüzyılın ortasına kadar sayıları belirli bir seviyede tutulduğu halde, özellikle yüzyılın dördüncü çeyreğinden itibaren önemli bir artı̧ göstermiştir.

Haklarında bilgi verilen mimarlara günlük ödenen ücretler göz önünde bulundurulduğunda, XVI. yüzyılda mimarbaşılar dışında kalan mimarlara yevmî verilen ücretin mimarların bilgi, beceri, tecrübe ve Hassa Mimarlar Ocağı'ndaki konumlarına göre 23 ilâ 5 akçe arasında değiştiği görülmektedir.

Bu çalışma, 1995-2000 yılları arasında Osmanlı Arşivi ile Topkapı Sarayı Müzesi Arşivi'nde yaptığımız uzun süreli araştırmalarda elde edilen bilgiler çerçevesinde, genel olarak orijinal kaynaklara dayanılarak hazırlanmıştır. Dolayısıyla XVI. yüzyıl Osmanlı mimarlarının büyük bir bölümü ilk defa bu araştırmada bir araya getirilerek topluca tanıtılmıştır.

\section{KAYNAKLAR}

\section{A) ARŞIV BELGELERi}

\section{1-Başbakanlık Osmanlı Arşivi Belgeleri}

Kamil Kepeci (KK), nr. 62, 242, 253.

Kamil Kepeci Ru'ûs Kalemi (KK, A. RSK), nr. 218, 244, 246, 248, 253.

Mühimme Defterleri (MD), nr. 2, 4, 7, 10,16, 21, 25, 35, 42, 52.

Ru'ûs Kalemi (A. RSK), nr. 1461.

Maliyeden Müdevver Defterler (MAD), nr. 2775, 7118, 559.

Küçük Rûznâmçe Kalemi (D. KRZ), nr. 33118.

\section{2-Topkapı Sarayı Müzesi Arşivi Belgeleri}

D. $9706 / 2$, D. 1801 , D. 3902, D. $1684 / 5$, D. 10137.

\section{B) ŞER'IYE SICILLERI}

Konya Şer'iye Sicili, nr.2

\section{C) DİĞER KAYNAKLAR}

AFYONCU, Erhan, "XVI. Yiizyılda Hassa Mimarları", Prof. Dr. Ismail Aka Armă̆an, İzmir 1999, s. 207-215. 
AHMED RIFAT EFENDİ, Lügat-ı Tarihiyye ve Coğrafiyye, Cilt: 1-2, İstanbul 1299.

AKTEPE, M. Münir, "Kosova", İslâm Ansiklopedisi, Cilt:6-2, Maarif Basımevi, İstanbul 19.54, s.869-876.

ALTINAY, Ahmet Refik, Türk Mimarlarn, (Hazırlayan: Zeki Sönmez), Sander Yayınları İstanbul 1977.

AnaBritannica, Cilt: 9, 19 ve 16, İstanbul 1988, 1989, 1990.

ASLANAPA, Oktay, Osmanlı Devri Mimarîsi, İnkılâp Kitapevi, İstanbul 1986.

AYVERDİ, Ekrem Hakkı, Avrupa'da Osmanlı Mimarî Eserleri Yugoslavya, II.

Cild, 3. Kitap, Baha Matbaası, İstanbul 1981.

BARKAN, Ömer L., Süleymaniye Cami ve Imareti Inşaatı (J550-1557), Cilt:1-2 Türk Tarih Kurumu Basımevi, Ankara 1972, 1979.

5 Numaralı Mühimme Defteri, Başbakanlık Devlet Arşivleri Genel Müdürlüğü Osmanlı Arşivi Daire Başkanlığı Yayınlanı / 21, Ankara 1994.

DANIŞMEND, İsmail Hami, İzahlı Osmanlı Tarihi Kronolojisi, 3. Cilt, İstanbul 1950.

DÜNDAR, Abdulkadir, "Osmanlı Mimarisinde Hassa Mimarları", Dinî Araştırmalar, Osmanlı Özel Sayısı, Cilt: 2, Sayı: 5, Eylül- Aralık 1999, s.159176.

,"Osmanh Mimarisinde Vilâyet (Eyâlet) Mimarları", XI. Milletlerarası Türk Sanatları Kongresi, Utrecht-The Netherlands, August 23-28, 1999, (Basılmamış bildiri).

, Arşivlerdeki Plân ve Çizimler Işı̆̆̆ Altında Osmanlı Imar Sistemi (XVIII. ve XIX. Yüzyll), Kültür Bakanlığı Yayınları / 2480, Ankara 2000. "Karapınar Sultan Selim Câmii'nin Mimarı Hakkında Yeni Bir Kayıt ve

Bazı Mülahazalar",Türkiye Bïyük Millet Meclisi'nin Açıllşının 80. Yıldinümü,

Karapinar Sempozyumu, (26-27 Ekim 200), (Editör: Yusuf Küçükdağ), Konya- Karapınar Belediyesi Yayın No:4, Konya 2001, s.165-174.

"16. Yüzyılda Suriye, Mısır ve Suudi Arabistan"daki İmar ve İnşâ

Faaliyetlerine Katkıda Bulunan Bazı Osmanlı Mimarları”, Ortadoğu'da Osmanlı Dönemi Kültür İzleri Uluslararası Bilgi Şoleni Bildirileri (25-27 Ekim Hatay, 28

Ekim İskenderun), Cilt: I, Atatürk Kültür Merkezi Yayınları, Kongre ve Sempozyum Bildirileri Dizisi / 20, Ankara 2001, s. 219-228

ERDENEN, Orhan, "Osmanlı Devri Mimarları, Yardımcıları ve Teşkilâtları", Mimarlik, 4. Yil, Sayı: 27, Ocak 1996, s.15-18.

"Osmanlılarda Mimarlık Teşkilâtı", Hayat Tarih Mecmuası, II/12 (1stanbuI 1967), s.47-50.

ERDOĞAN, Muzaffer. "Mimar Davud Ağa’nın Hayatı ve Eserleri”, Tïrkiyat Mecmuası, Cilt: 12, Osman Yalçın Matbaası, İstanbul 1955, s.179-204.

HAFIZ HÜSEYIN AYVANSARAYÎ, Hadikatii'l-Cevâmi, Cilt. I-II, Matbaa-i Amire, Sene 1281.

İBN MANZÛR, Lisanu'l-Arab, Cilt: II. Beyrut 1956.

KARAL, Enver Ziya, Osmanlı Tarihi, Vl. Cilt, 3. Baskı, Türk Tarih Kurumu Basimevi, Ankara 1983, s.251. 
KOMISYON, Fâtih Câmileri, Türkiye Diyanet Vakfı Fâtih Şubesi Yayınları, İstanbul 1987.

KURAN, Aptullah, Mimar Sinan, Hürriyet Vakfı Yayınları, İstanbul 1986.

KÜÇÜKDAĞ,Yusuf, Karapınar Sultan Selim Külliyesi, Karapınar Belediyesi KültürYayını no:3, Konya 1997.

MARTAL, Abdullah, "XVI. Yüzyılda Osmanlı İmparatorluğunda Su-Yolculuk ", Belleten, LII / 205 (1988), s.1585-1653.

MEHMED SÜREYYA, Sicill-i Osmânî, (Haz: Nuri Akbayar), Cilt:4, Tarih Vakfı Yurt Yayınları, İstanbul 1996.

MERIÇ, Rıfkı Melûl, "Beyazıd Câmii Mimârı II. Sultan Bayezıd Devri Mimarları İle Bazı Binaları Beyazıd Câmii Ile Alâkahı Hususlar, San'atkârlar ve Eserleri”, Yıllık Araşurmalar Dergisi II, Ajans-Türk Matbaası, Ankara 1958, s.4-76.

MUSTAFA NURİ PAŞA, Netayic ül-Vukuat Kurumları ve Örgütleriyle Osmantl Tarihi. Cilt: I-II. (Sadeleştiren: Neşet Çağatay), Türk Tarih Kurumu Basımevi, Ankara 1987.

MÜDERRISOǦLU, Fatih, 16.Yüzyılda Osmanlı Imparatorluğu'nda Inşâ Edilen Menzil Külliyeleri, (H.Ü.Sos.Bilim.Ens. Basılmamı̧ Doktora tezi), Cilt.l, Ankara Ekim, 1993.

NAZIF HOCA, "Üsküp", İslâm Ansiklopedisi, Cilt:13, Milli Eğitim Basımevi, İstanbul 1986, s.122-127.

12 Numaralı Mühimme Defteri, I, Başbakanlık Devlet Arşivleri Genel Müdürlüğü Osmanlı Arşivi Daire Başkanlığı Yayınları / 33, Ankara 1996.

ORGUN, Zarif, "Hassa Mimarları", Arkitekt, Cumhuriyet Matbaası, İstanbul 1939, s.3-12.

ORHONLU, Cengiz, "Şehir Mimarları", Osmanlı Araştırmaları, II, İstanbul 1981, s.1-30.

ÖZ, Tahsin, Istanbul Câmileri, I. Cilt, Türk Tarih Kurumu Basımevi, Ankara 1987.

SÖNMEZ, Zeki, "Mimar Sinan ve Hassa Mimarlar Ocağı", Mimar Sinan Dönemi

Türk Mimarlı̆̆ı ve Sanatı, (Haz: Zeki Sönmez), İstanbul 1988, s.251-258.

ŞEMSEDDIN SAMİ, Kâmûsu'l-A'lâm, Cilt: 4, İstanbul 1314(1896).

TURAN, Şerafettin, "Osmanlı Teşkilâtında Hassa Mimarları", Tarih Araştırmaları Dergisi, Cilt: 1, Say1: 1, Ankara Universitesi Basımevi 1964, s.157-202.

Türk Ansiklopedisi, Cilt:28, 33, Milli Eğitim Basımevi, Ankara 1980, 1984. 